Research paper

\title{
Ynamide Click chemistry in development of triazole VEGFR2 TK modulators
}

\author{
Margaréta Vojtičková a, b, Juraj Dobiaš ${ }^{\mathrm{b}}$, Gilles Hanquet ${ }^{\mathrm{a},{ }^{* *}}$, Gabriela Addová c, \\ Rengul Cetin-Atalay ${ }^{\mathrm{d}}$, Deniz Cansen Yildirim ${ }^{\mathrm{e}}$, Andrej Boháč b, f, * \\ ${ }^{a}$ Université de Strasbourg, Ecole européenne de Chimie, Polymères et Matériaux (ECPM) Laboratoire de Synthèse et Catalyse (UMR CNRS 7509), 25, \\ rue Becquerel, F-67087 Strasbourg, France \\ ${ }^{\mathrm{b}}$ Comenius University in Bratislava, Faculty of Natural Sciences, Department of Organic Chemistry, Mlynská dolina, 84215 Bratislava, Slovakia \\ ${ }^{\mathrm{c}}$ Institute of Chemistry, Mlynská dolina, 84215 Bratislava, Slovakia \\ d Cancer Systems Biology Laboratory, Graduate School of Informatics, METU, 06800 Ankara, Turkey \\ e Department of Molecular Biology and Genetics, Faculty of Science, Bilkent University, Ankara, Turkey \\ f Biomagi, Ltd., Mamateyova 26, 85104 Bratislava, Slovakia ${ }^{1}$
}

\section{A R T I C L E I N F O}

Article history:

Received 15 July 2014

Received in revised form

5 August 2015

Accepted 6 August 2015

Available online 8 August 2015

Keywords:

Oxazole/1,2,3-triazole isosteric replacement Ynamide

CuACC Click chemistry

VEGFR2 tyrosine kinase inhibition

Cytotoxic activity in Huh-7 and Mahlavu

hepatocellular carcinoma cell lines

PI3K/Akt pathway

\begin{abstract}
A B S T R A C T
Structure novelty, chemical stability and synthetic feasibility attracted us to design 1,2,3-triazole compounds as potential inhibitors of VEGFR2 tyrosine kinase. Novel triazoles T1-T7 were proposed by oxazole (AAZ from PDB: 1Y6A)/1,2,3-triazole isosteric replacement, molecular modelling and docking. In order to enable synthesis of T1-T7 we developed a methodology for preparation of ynamide $\mathbf{2 2}$. Compound 22 was used for all Click chemistry reactions leading to triazoles T1-T3 and T6-T7. Among the obtained products, T1, T3 and T7 specifically bind VEGFR2 TK and modulate its activity by concentration dependent manner. Moreover predicted binding poses of T1-T7 in VEGFR2 TK were similar to the one known for the oxazole inhibitor AAZ (PDB: 1Y6A). Unfortunately the VEGFR2 inhibition by triazoles e.g. T3 and T7 is lower than that determined for their oxazole bioisosters T3-ox and AAZ, resp. Different electronic properties of 1,2,3-triazole/oxazole heterocyclic rings were proposed to be the main reason for the diminished affinity of T1-T3, T6 and T7 to an oxazole AAZ inhibitor binding site in VEGFR2 TK (PDB: 1Y6A or 1Y6B). Moreover T1-T3 and T6 were screened on cytotoxic activity against two human hepatocellular carcinoma cell lines. Selective cytotoxic activity of T2 against aggressive Mahlavu cells has been discovered indicating possible affinity of $\mathbf{T} 2$ to Mahlavu constitutionally active PI3K/Akt pathway.
\end{abstract}

(c) 2015 Elsevier Masson SAS. All rights reserved.

\section{Introduction}

Anti-angiogenesis agents that target malignant vasculature are of considerable interest due to their perceived potential to target tumour resistance towards chemo- and radiotherapy [1,2]. Vascular endothelial growth factors (VEGFs) and their corresponding family of receptor tyrosine kinases (VEGFRs) are the key proteins

\footnotetext{
* Corresponding author. Comenius University in Bratislava, Faculty of Natural Sciences, Department of Organic Chemistry, Mlynská dolina, 84215 Bratislava, Slovakia.

** Corresponding author.

E-mail addresses: vojtickova.margareta@gmail.com (M. Vojtičková),jur.dobias@ gmail.com (J. Dobiaš), ghanquet@unistra.fr (G. Hanquet), addova@fns.uniba.sk (G. Addová), rengul@bilkent.edu.tr (R. Cetin-Atalay), andrej.bohac@fns.uniba.sk (A. Boháč).

1 http://www.mch.estranky.sk/clanky/biomagi.html
}

modulating angiogenesis, the formation of new vasculature from an existing blood network. These include VEGFR1 (Flt1), VEGFR2 (Kinase Insert Domain Receptor (KDR) or Flk1). The last one, VEGFR3 is specialized for lymphagiogenesis [3]. VEGFR2 is the major positive signal transducer for endothelial cells proliferation and differentiation [4]. There has been considerable evidence, including clinical observations, that the abnormal angiogenesis is implicated in a number of diseases including rheumatoid arthritis, inflammation, degenerative eye conditions and cancer $[5,6]$.

Cancer stem cells (CSCs) represent a small but the most tumourigenic subpopulation from the tumour cells responsible for metastasis, tumour recurrence and drug resistance. CSCs, also called "the roots of cancer", are considered to be a new promising therapeutic target [7]. VEGFR2 is regarded as an endothelial cell protein but evidences suggest that VEGFRs may be expressed also by cancer cells. Glioblastoma multiforme (GBM) is characterized by 
florid vascularisation and aberrantly elevated VEGF. Antiangiogenic therapy with bevacizumab reduces GBM tumour growth. VEGFR2 is expressed on CD133 + human glioma cancer stem cells (GCSCs). VEGF-VEGFR2-Neuropilin1 (NRP1) axis influences GCSCs viability, self-renewal, and tumourigenicity. GCSCs viability was attenuated by direct inhibition of VEGFR2 TK activity and/or knockdown of VEGFR2 or NRP1. VEGFR2 inhibitors may block the VEGF-VEGFR2NRP1 pathway $[8,9]$. VEGF via VEGFR2 stimulates proliferation of glioblastoma multiform CSCs. VEGF stimulates GCSCs tumourigenesis and angiogenesis. Suppression of VEGFR2 signalling is therefore a potential therapeutic strategy in GBM [10]. VEGFR2 plays a key role in ability of glioblastoma CSCs to vasculogenic mimicry (VM) formation, neovascularisation and tumour initiation. Knockdown of VEGFR2 in GCSCs markedly reduced their selfrenewal, forming tubules, initiating xenograft tumours, promoting vascularisation and the establishment of VM. VEGFR2 is an essential molecule to sustain the "stemness" of GCSCs, their capacity to initiate tumour vasculature, and direct initiation of tumours [11]. Therefore VEGFR2 inhibitors are important compounds reducing angiogenesis and promising compounds to interfere with CSCs resistance.

The PDB database contains VEGFR2 TK complex 1Y6A possessing $\mathrm{N}$-aryl-5-aryloxazol-2-amine ligand $\mathbf{A A Z}$ (Fig. 1) determined as a powerful VEGFR2 inhibitor ( $\mathrm{IC}_{50}: 22 \mathrm{nM}$ ). Ligand $\mathbf{A A Z}$ was prepared in five steps in a low overall $10 \%$ yield mostly due to the problematic oxazole-2-amine fragment formation [12]. Low yields of oxazole-2-amine formation $(1-58 \%$ ) have been also described $[13,14]$. Moreover $\mathbf{A A Z}$ contains $N$-aryloxazol-2-amine part that uses to liberate from connection with oxazole by influence of nucleophilic reagent (e.g. amines, alkoxides etc.). Nucleophilic attack on $\mathrm{C}(2)$ of $\mathbf{A A Z}$ oxazole ring resulting in toxic aniline $\mathbf{2 6}$ (Scheme 1). (unpublished results) Low yielding synthesis of $\mathrm{N}$ aryloxazol-2-amines, their problematic stability and potential toxicity resulting from releasing aniline inspired us to develop novel, stable and synthetically more feasible VEGFR2 modulators based on the oxazole/1,2,3-triazole isosteric replacement. (Fig. 1) Replacing the heterocyclic ring in the structure of some inhibitors can provide a novel compounds with improved properties [15].

1,4-Disubstituted 1,2,3-triazoles are stable compounds easily obtainable in high yields from organic alkynes and azides by $\mathrm{Cu}(\mathrm{I})$ catalyzed reaction (CuACC Click chemistry) [16]. Click reaction allows rapid preparation of different triazoles that is especially advantageous if one of the reactants is the same in all performed reactions (e.g. ynamide 22a in our case, Schemes 8 and 11). Additionally, Click reaction can selectively provide also 1,5regioisomeric compounds via Ru (II) catalyzed cycloaddition [17] (Fig. 1).

Only few active 1,2,3-triazole containing VEGFR2 TK inhibitors are described in the literature: 6 inhibitors $\mathbf{1}-\mathbf{6}$ possessing

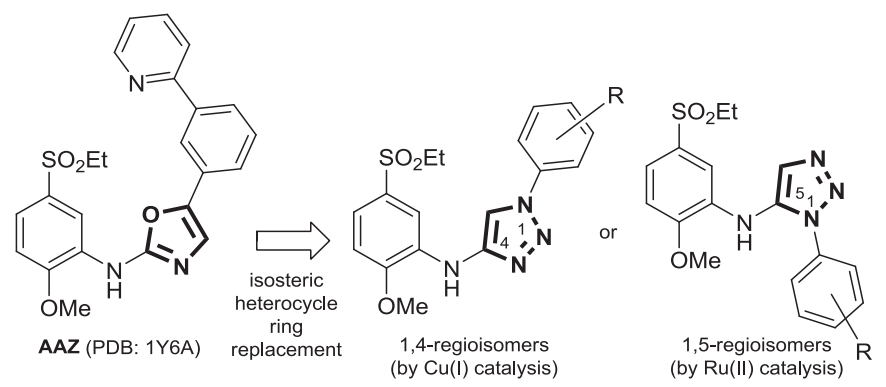

oxazole

regioisomeric 1,2,3-triazoles

Fig. 1. The isosteric oxazole/1,2,3-triazole replacement. Click reaction can produce selectively one of the two triazole regioisomers based on different catalytic conditions.
$\mathrm{IC}_{50}<50 \mathrm{nM}$, (Fig. 2) 10 substances with $\mathrm{IC}_{50}<100 \mathrm{nM}$ and 19 compounds having $\mathrm{IC}_{50} \leq 200 \mathrm{nM}[18]$.

Imidazopyridazine $\mathbf{1}$ is the most active 1,2,3-triazole containing VEGFR2 inhibitor ( IC $\left._{50}: 1.2 \mathrm{nM}\right)[19]$. Other active inhibitors are e.g. benzoxazolamine 2 ( $\mathrm{IC}_{50}: 8 \mathrm{nM}$ ) [20], quinazolinamines 3 and 4 ( $\mathrm{IC}_{50}$ : 10 and $30 \mathrm{nM}$, resp.) [21,22], indazolurea 5 ( $\left.\mathrm{IC}_{50}: 45 \mathrm{nM}\right)$ [23] and ureidopyridine-N-oxide 6 ( $\left.\mathrm{IC}_{50}: 49 \mathrm{nM}\right)$ [24]. All of these VEGFR2 inhibitors (Fig. 2) possess a terminal 1,2,3-triazole fragment. In these cases, triazole group need not contribute to the inhibitor target affinity. Triazole group can be used to improve the ligand pharmacokinetic properties. E.g. the most potent inhibitor 1 $\left(\mathrm{IC}_{50}: 1.2 \mathrm{nM}\right.$ ) was designed by pyrazole/triazole isosteric replacement in the structure of ligand from PDB complex 3VO3. In case of PDB: 3 VO3 a pyrazole ring does not bind the VEGFR2 TK directly. It is exposed towards the solvent accessible part of the protein [19]. Therefore triazole core that replaces a pyrazole ring can have the same position. Compound $\mathbf{7}$ is a close analogue of sunitinib that is an active base of the drug Sutent (Pfizer Inc.). Sunitinib inhibitory activity $\mathrm{IC}_{50}=39 \mathrm{nM}$ (VEGFR2 TK) was determined [25]. The structure 7 possesses $\mathrm{N}-1,2,3$-triazolylethyl group instead of $\mathrm{N}, \mathrm{N}$ diethylaminoethyl group present in sunitinib (Fig. 3). Recently an X-ray structure of VEGFR2 TK/sunitinib complex (PDB: 4AGD) appeared [26]. From its analysis is clear that the N,N-diethylamino group in sunitinib is exposed out of the VEGFR2 protein and represents only a group improving the ligand pharmacokinetic profile.

Although X-ray structure of complex 7 with VEGFR2 kinase is not known, an analogous function can be expected also for the triazole group in $\mathbf{7}$ (Fig. 3).

Only few VEGFR2 TK inhibitors possessing internal 1,2,3-triazole core were found in the literature. Compounds 8-10 were described as VEGFR2 activity modulators ( $\mathrm{K}_{\mathrm{i}}>915 \mathrm{nM}$ (VEGFR2)) [27]. The staurosporin-like inhibitor $\mathbf{1 1}$ moderately influences the VEGFR2 kinase activity ( IC $_{50}$ : $200 \mathrm{nM}$ ) [28] (Fig. 4).

Kiselyov et al. described the most active VEGFR2 inhibitors 12-14 ( IC $_{50}: 51-87 \mathrm{nM}$ ) possessing an internal 1,2,3-triazole core [29] (Fig. 5).

Our docking results proposed that the triazole fragment in 12-14 directly contributes the binding with VEGFR2 TK. The predicted intermolecular interactions of $\mathbf{1 2}$ and $\mathbf{1 4}$ are depicted on Fig. 6. Moreover proposed positions of the above triazole inhibitors in VEGFR2 ATP active site is similar to the poses of ligands from PDB complexes 2P2I (IC $50: 38 \mathrm{nM}$ ), and 3EFL (IC $50: 3 \mathrm{nM}$ ). (not shown) Both VEGFR2 kinase conformers (PDB: 2P2I and 3EFL) used in docking experiments are VEGFR2 inactive (DFG-out) kinases originally accommodating Type II inhibitor [14].

Considering the data mentioned above, we decided to prepare VEGFR2 TK modulators T1-T7 possessing an internal 1,2,3-triazole core and determine their VEGFR2 TK inhibition potential.

\section{Results and discussion}

\subsection{Interaction analysis of $A A Z$ conformers}

Oxazole VEGFR2 TK inhibitor AAZ was developed by GlaxoSmithKline [12]. The intermolecular interactions for both $\mathbf{A A Z}$ conformers present in VEGFR2 TK complex PDB: 1Y6A are depicted on Fig. 7.

Based on the above analysis, we decided to keep the pharmacophorically interesting 5-(ethylsulfonyl)-2-methoxyphenylamine fragment from $\mathbf{A A Z}$ ligand in all predicted triazole structures T1-T7. (Fig. 10) The proposed intermolecular interactions of triazoles T1-T7 and their poses in VEGFR2 kinase were similar to those known for AAZ ligand from PDB complex 1Y6A. (e.g. T3 from Fig. 12). 
A: Corey-Fuchs

B: Bestmann-Ohira

C: Speziale-Smith

D: Skrydstrup-Hsung's<smiles>C1CCCCCCC1</smiles><smiles>C#CN(C)c1cc(S(C)(C)C)ccc1OC</smiles><smiles>[B]1C=CCCC1</smiles><smiles>CCOS(=O)(=O)c1ccc(OC)c(N(C=C(Cl)Cl)C(C)(C)C)c1</smiles><smiles>C1=CCCC=C1</smiles>

EWG: Boc- (23b)

Ts- (23c)

Piv- (23d)<smiles>COP(=O)(OC)C(=N)C(C)=O</smiles>

25<smiles>C=CCC</smiles>

$E W G=\mathrm{MeOOC}-(22 a)$

Boc-

Ts-

Piv-
$(22 b)$

(22c)

(22d)

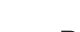<smiles>CCOS(=O)(=O)c1ccc(OC)c(N(C(Cl)=C(Cl)Cl)C(C)(C)C)c1</smiles>

EWG: Ts- (27c)<smiles>CCOS(=O)(=O)c1ccc(OC)c(N(C=O)C(C)(C)C)c1</smiles>

EWG: Boc- (24b)

Ts- (24c)

Piv- (24d)

EWG: Ts- (24c)<smiles>CCOS(=O)(=O)c1ccc(OC)c(N(C(=O)C(Cl)(Cl)Cl)C(C)(C)C)c1</smiles>

EWG: Ts- (28c)<smiles>CCCCCc1cc(OCC)c(N)cc1CCCC</smiles><smiles>[C]1CC1</smiles><smiles>C1=C[Te]C1</smiles>

26

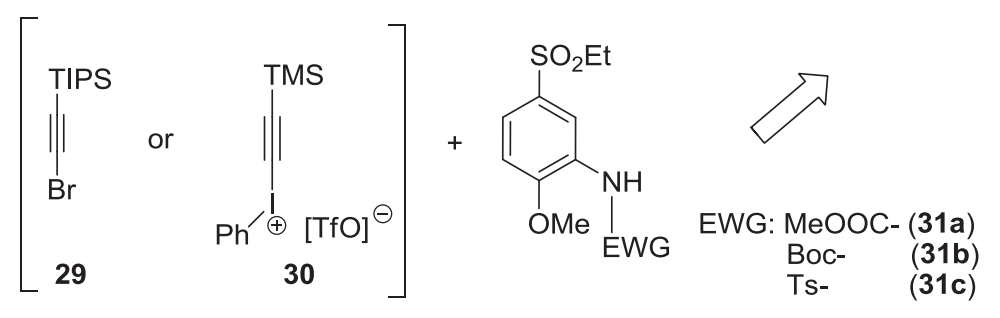

Scheme 1. Proposed retrosynthetic approach to ynamides 22a-d.

\subsection{In Silico predictions}

An interaction analyse, molecular modelling and docking were used to identify the skeletons of 1,2,3-triazole derivatives T1-T7. (Fig. 10) A reduced success of in Silico predictions is often associated with the ligand based target induced fit [30-32]. Therefore, for our docking experiments we selected the kinase variants of VEGFR2 from PDB complexes 1Y6A and 1Y6B possessing structurally the most relative oxazole ligands ( $\mathbf{A} \mathbf{A Z}$ and $\mathbf{A A X}$, resp.). These ligands represent Type I, ATP competitive VEGFR2 inhibitors that bind to an exceptional inactive VEGFR2 tyrosine kinase possessing an opened activation loop as was discovered by us recently [14]. Because the structure similarity between $\mathbf{A A Z}(\mathbf{A} \mathbf{A X})$ and proposed triazoles (e.g. T7, T6, T3 and T5) we did not expect strong influence of triazole ligand based induced fit. On the other hand, it was not easy to find triazole structures possessing AAZ-like score and pose by docking. The initial in Silico experiments were performed by an older DOCK software version with a kinase taken from PDB complex 1Y6B [33].

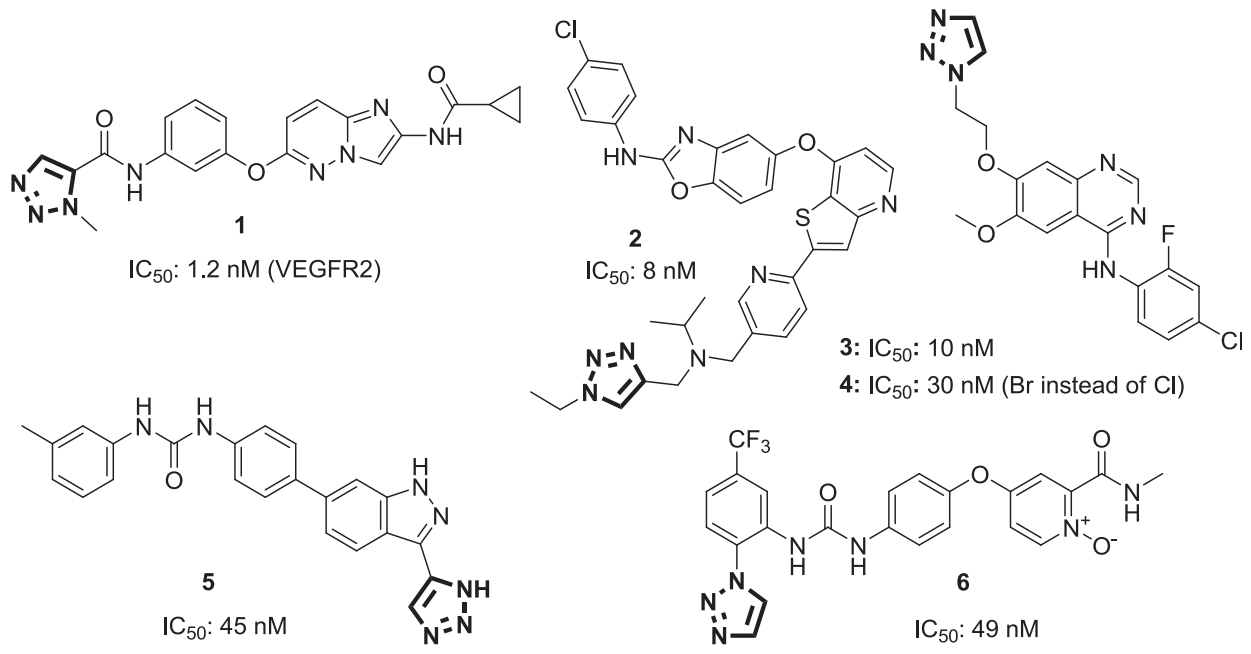

Fig. 2. The structures of VEGFR2 TK inhibitors 1-6. 


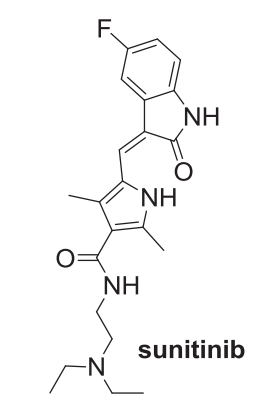

$\mathrm{IC}_{50}: 39 \mathrm{nM}(\mathrm{VEGFR2})$
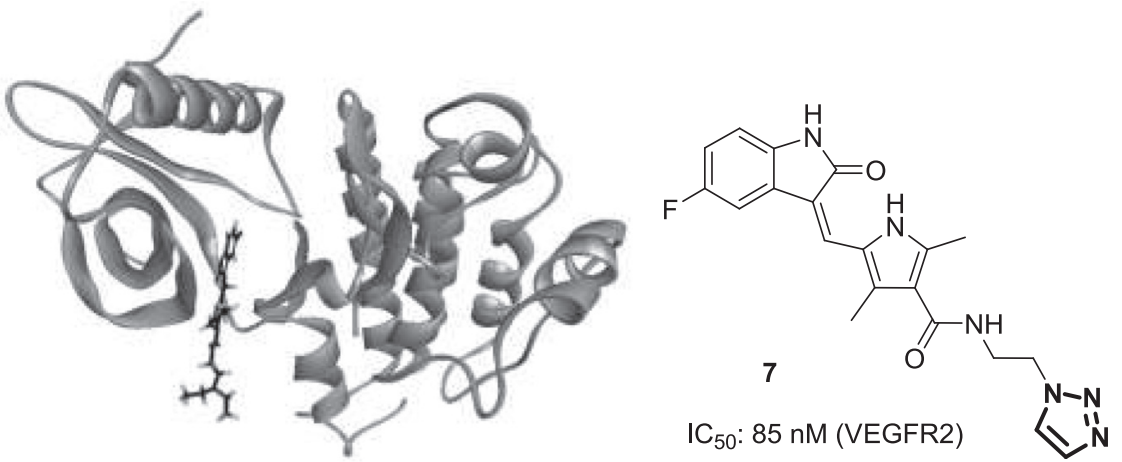

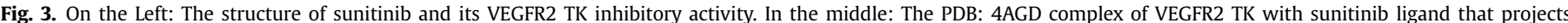

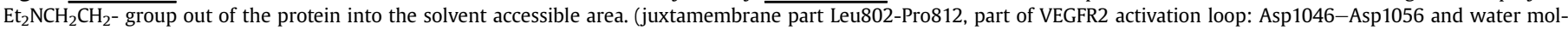
ecules were omitted for clarity). On the right: The structure of 1,2,3-triazole containing inhibitor 7 (mimicking sunitinib).

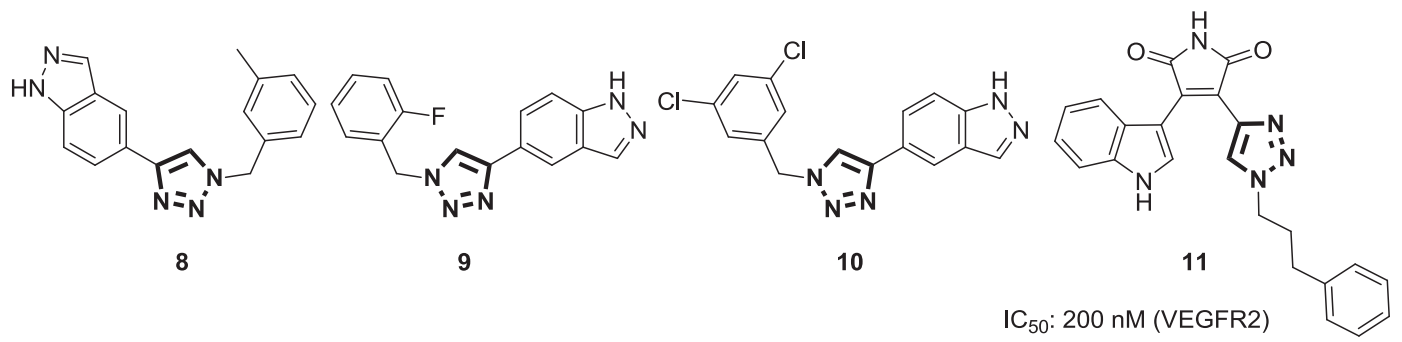

Fig. 4. VEGFR2 modulators $\mathbf{8}-\mathbf{1 1}$ possessing an internal 1,2,3-triazole core.<smiles>FC(F)(F)c1cccc(-n2cc(-c3ccccc3NCc3ccncc3)nn2)c1</smiles>

$\mathrm{IC}_{50}: 51 \mathrm{nM}$<smiles>FC(F)(F)Oc1cccc(-n2cc(-c3ccccc3NCc3ccncc3)nn2)c1</smiles>

$\mathrm{IC}_{50}: 66 \mathrm{nM}$<smiles>Clc1cccc(-n2cc(-c3ccccc3NCc3ccncc3)nn2)c1</smiles>

$\mathrm{IC}_{50}: 87 \mathrm{nM}$

Fig. 5. Potent VEGFR2 inhibitors 12-14 with an internal 1,2,3-triazole ring.

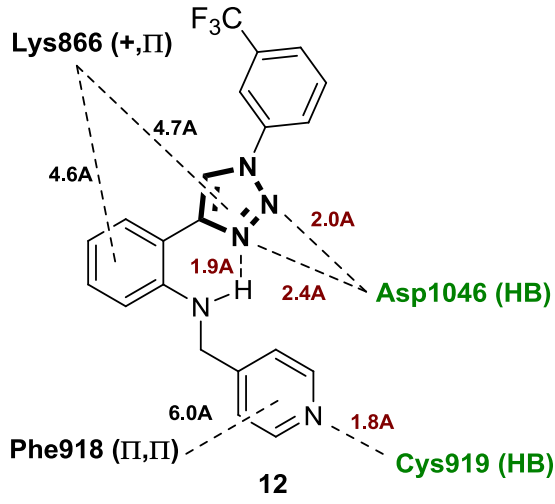

$\mathrm{IC}_{50}$ : $51 \mathrm{nM}$ score: $-54.1 \mathrm{kcal} / \mathrm{mol}(2 \mathrm{P} 2 \mathrm{I})$

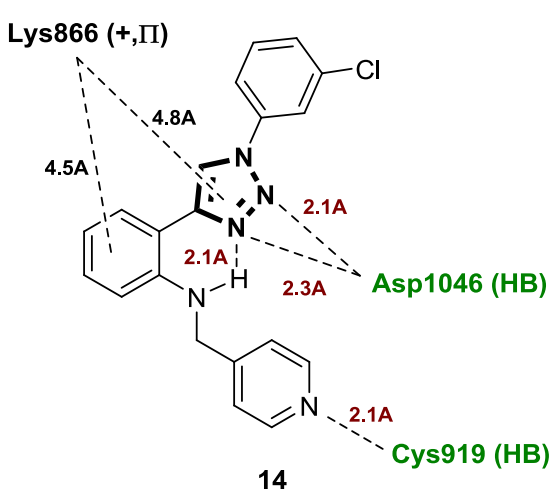

$\mathrm{IC}_{50}: 87 \mathrm{nM}$ score: $-58.1 \mathrm{kcal} / \mathrm{mol}(3 \mathrm{EFL})$

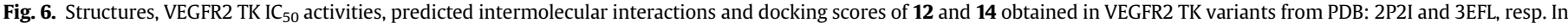

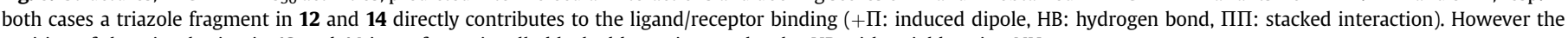
position of the triazole ring in $\mathbf{1 2}$ and $\mathbf{1 4}$ is conformationally blocked by an intermolecular HB with neighbouring $\mathbf{N H}$ group. 

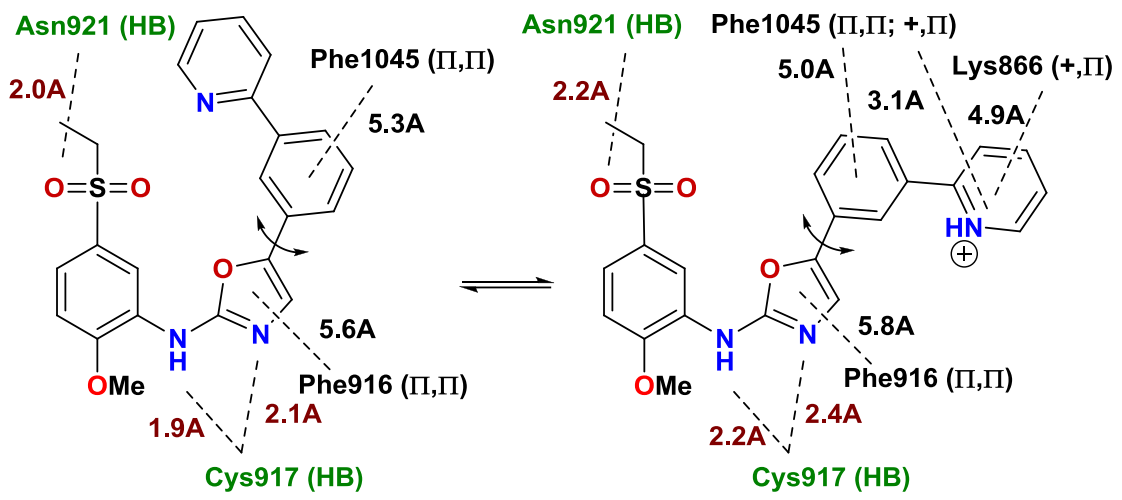

U-shaped conformer $\quad$ AAZ $\left(\mathrm{IC}_{50}: 22 \mathrm{nM}\right) \quad$ S-shaped conformer

Fig. 7. The intermolecular interactions for both AAZ conformers present in VEGFR2 TK complex PDB: 1Y6A.

Some 1,4-disubstituted triazole skeletons that fulfilled both required score (AAZ: $-53.6 \mathrm{kcal} / \mathrm{mol}$ ) and pose conditions were selected: e.g. T3 (score -57.2$)$, T5 (-52.9), T6 (-51.3), T2 (-51.3), T4 (-49.2). The triazole core of $\mathbf{T} \mathbf{1}-\mathbf{T} 7$ retains predicted hydrogen bond interaction with the kinase backbone amino acid residue Cys917 an important interaction known from AAZ oxazole ring in PDB: 1Y6A (Fig. 7). Pharmacokinetic properties of triazoles T1 - T7 predicted by Molinspiration toolkit supported their drug-likeness [34-38] (see supporting material). Proposed properties for 1,4regioisomeric triazoles $\mathbf{T 1}-\mathbf{T 7}$ were promising. Therefore we decided to perform their synthesis. 1,5-Regioisomeric triazole analogues (Fig. 1) of T1-T7 were also docked by the same conditions. All these compounds were less advantageous possessing lower docking scores and several of them did not retain expected AAZlike pose in VEGFR2 TK. (not shown) Therefore 1,5-regioisomers were omitted.

For the synthesis of all 1,4-disubstituted 1,2,3-triazoles T1-T7 the pharmacophoric ynamide $\mathbf{2 2}$ (in modifications 22a-22d) was required. (Schemes 8, 9 and 11) Its synthesis was developed starting from aniline derivative $\mathbf{2 6}$. (Scheme 1 ).

\subsection{Synthesis}

In order to obtain compounds T1-T7 (Fig. 10), we started synthesis their precursors azides 15-21 and ynamides 22a-22d (Fig. 8).

\subsubsection{Preparation of ynamides $\mathbf{2 2 a}, \boldsymbol{b}$}

Ynamides are stabilized equivalents of the corresponding reactive ynamines $[39,40]$. Diminishing the electron-donating ability of ynamine nitrogen by its protection with an electron-withdrawing group (EWG) leads to more stable ynamides. Since the first synthesis of ynamides reported by Viehe in 1972 [41], different methods have been published and the possible pathways towards required ynamides 22a,d are summarized in Scheme 1. Starting 5(ethylsulfonyl)-2-methoxyaniline (26) was prepared from commercially available 4-methoxybenzenesulfonyl chloride according to a recently described procedure in four steps and 59\% overall yield [42].

Corey-Fuchs alkynylation proved to be ineffective in our hands. (Scheme 1, Path A) In fact, application of the Brückner procedure [43] on protected formamides $\mathbf{2 4}$, which have to be protected with an EWG protecting group prior to their formylation, was successful only in the case of the corresponding dichlorovinyl intermediate 23c (tosyl protecting group) in a very modest yield (9\%), and therefore this path was abandoned. The Bestmann-Ohira alkynylation (Scheme 1, Path B) was ineffective with $\mathbf{2 4 c}$ and only starting material was recovered [44]. A transformation of $\mathrm{N}$-trichloroacetate $\mathbf{2 8 c}$ to the corresponding ynamide 22c according to the methodology of Speziale and Smith has been tested [45]. (Scheme 1, Path $\mathrm{C}$ and Scheme 2) Treatment of $\mathrm{N}$-trichloroacetate 28c obtained from $N$-tosyl-aniline 31c with $\mathrm{PPh}_{3}$ in refluxing toluene led to a mixture of uncharacterized products. (Scheme 2).

An exciting expansion in ynamide chemistry $[46,47]$ has been initiated by the pioneer work of Stang and Kitamura who prepared ynamides by reaction of alkynyl iodonium triflates [48] or tosylates [49] with lithium amides. Unfortunately, this methodology applied to amides $\mathbf{3 1 a , b}$ and iodonium triflate $\mathbf{3 0}$ failed. (Scheme 1, Path D) Inspired by Buchwald's copper-catalyzed $N$-alkynylations of amides [50], practical cross-coupling between amides and alkyne bromides have been developed using copper salts $\left(\mathrm{CuSO}_{4} \cdot 5 \mathrm{H}_{2} \mathrm{O}\right.$ [51], CuI, $\mathrm{Cu}_{2} \mathrm{O}, \mathrm{Cu}(\mathrm{OAc})_{2}$ ) or simple copper powder. Later on, W. Tam [52] significantly improved the yield of ynamides by using modified reaction conditions $(0.20-0.30$ eq of CuI, $0.22-0.36$ eq of the $1,10-$ phenanthroline ligand and adding 1.20 eq of the base KHMDS slowly over $3-4 \mathrm{~h}$ in toluene at $90{ }^{\circ} \mathrm{C}$ ). In 2008 , Skrydstrup et al. [53] published the Hsung's second generation protocol where potassium phosphate or carbonate was used as the mild base instead of KHMDS. In this case, anhydrous $\mathrm{K}_{3} \mathrm{PO}_{4}$ provided higher ynamide yields (52-91\%). The latter conditions brought positive results and ynamides 22a,b were prepared from carbamates $\mathbf{3 1 a , b}$ and alkyne bromide 29 in 94 and 59\% yield respectively over two steps (Scheme 1, Path D and Scheme 3).

\subsubsection{Preparation of azides $\mathbf{1 5 - 2 1}$}

The synthesis of azides 15-19 and $\mathbf{2 1}$ was performed by a Suzuki-Miyaura cross coupling conditions followed by an aromatic substitution (Scheme 4).

According to this strategy, azides 15, 16,17 and 19 were prepared in 57 and $45 \%$ yield over two steps for 15 and 17, 33\% over three steps for $\mathbf{1 6}$ and $37 \%$ yield over seven steps for $\mathbf{1 9}$ starting from $p$ nitroaniline 37. (Scheme 5) Palladium catalyzed coupling of 2bromopyridine with boronic acid $\mathbf{3 3}$ in the presence of sodium carbonate in a mixture of water/ethanol and DME at $75{ }^{\circ} \mathrm{C}$ within $16 \mathrm{~h}$ [54] afforded biaryl bromide $\mathbf{3 4}$ which was treated with sodium azide and copper(I) iodide according to the procedure of Liang and co-workers to deliver azide 15 [55]. Subsequently a palladium-catalyzed acetoxylation of arene $\mathrm{C}-\mathrm{H}$ bond at ortho position to the pyridine-2-yl substituent has been performed by phenyliodine diacetate $\left(\mathrm{PhI}(\mathrm{OAc})_{2}\right)$ in acetic anhydride [56]. These conditions led regioselectively to azide $\mathbf{1 6}$ in 57\% yield. Biaryl bromide 36 was obtained from the Suzuki-Miyaura cross coupling 
<smiles>Nc1cccc(-c2ccccn2)c1</smiles>

15<smiles>CC(=O)Oc1ccc([N+](=O)[O-])cc1-c1ccccn1</smiles>

16<smiles>Nc1cccc(-c2cccnc2)c1</smiles>

17<smiles>N#[N+]c1ccc(O)c(-c2cccnc2)c1</smiles>

18<smiles>N#CNC(N)=O</smiles><smiles>Nc1nc(-c2ccccc2)cc(-c2ccccc2)n1</smiles><smiles>CC(=O)Oc1ccc(N)cc1-c1ccn(C(F)F)c1</smiles>

21<smiles>C#CN(C(C)=O)c1cc(S(=O)(=O)CC)ccc1OC</smiles>

$22 a$<smiles>C#CN(C(C)=O)c1cc(S(=O)(=O)OCC)ccc1OC</smiles>

22b<smiles>C#CN(CC)c1cc(S(=O)(=O)OCC)ccc1OC</smiles>

22c<smiles>C#CN(c1ccccc1)c1ccc(S(=O)(=O)OCC)cc1OC</smiles>

22d

TIPS: ' $\mathrm{Pr}_{3} \mathrm{Si}$; Tos: tosyl; Piv: pivaloyl

Fig. 8. Structures of required azides $\mathbf{1 5}-\mathbf{2 1}$ and ynamides $\mathbf{2 2 a}-\mathbf{2 2 d}$

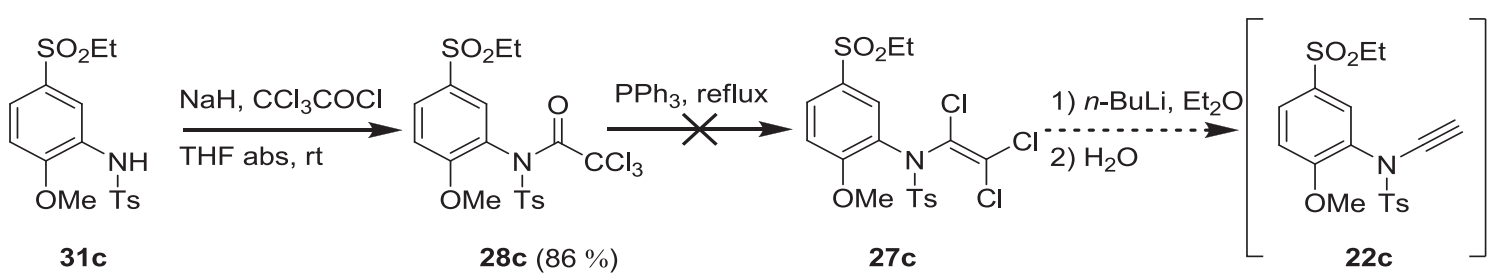

Scheme 2. An attempt for preparation of ynamide $22 \mathrm{c}$ via trichloroaetate $\mathbf{2 8 c}$.

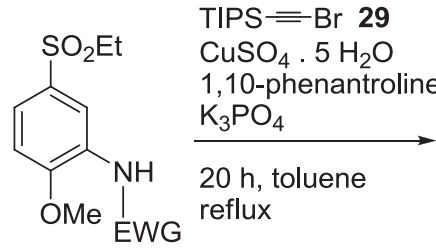

EWG: MeOOC- (31a)

Boc-

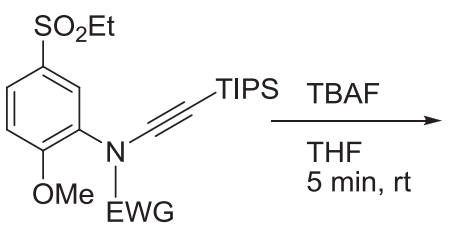

(32a) $97 \%$ (32b) $62 \%$<smiles>C#CN(C)c1cc(S(=O)(=O)OCC)ccc1OC</smiles>

(22a) $97 \%$ (22b) $95 \%$

Scheme 3. Successful synthesis of ynamides 22a,b via copper-mediated amide alkynylation.
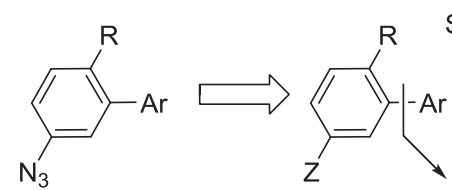

Suzuki-Miyaura
coupling coupling

15 - 19, 21

$\mathrm{R}: \mathrm{H}, \mathrm{OH}, \mathrm{OAc}, \mathrm{NHCONH}_{2}$ Ar: 2-py, 3-py, 1-napht, 3-pyrrol

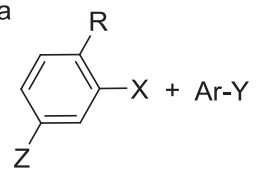

$\mathrm{X}=$ hal, $\mathrm{B}(\mathrm{OR})_{2}$

$\mathrm{Y}=\mathrm{B}(\mathrm{OR})_{2}$, hal

$\mathrm{Z}: \mathrm{Br}, \mathrm{NO}_{2}$

[54] between pinacolboronic ester 35 [57] and 1,3-dibromobenzene and converted to azide $\mathbf{1 7}$ using the Liang's protocol. (Scheme 5) Preparation of azide 19 started with ortho-iodination [58] of $p$ nitroaniline 37, followed by protection of amino group of the resulting iodide $\mathbf{3 8}$ as acetamide $\mathbf{3 9}$ [59] and subsequent Suzuki-Miyaura coupling with 1-naphtylboronic acid [60] to deliver biarylic compound $\mathbf{4 0}$ in $\mathbf{8 2} \%$ yield over three steps. The transformation of nitro derivative $\mathbf{4 0}$ to the corresponding azide $\mathbf{4 2}$ was performed in 2 steps via aniline $\mathbf{4 1}$ [61,62]. Deacetylation of $\mathbf{4 2}$ was performed under basic conditions. Finally, urea derivative 19 was prepared from unstable amino azide $\mathbf{4 3}$ by trichloroacetyl 

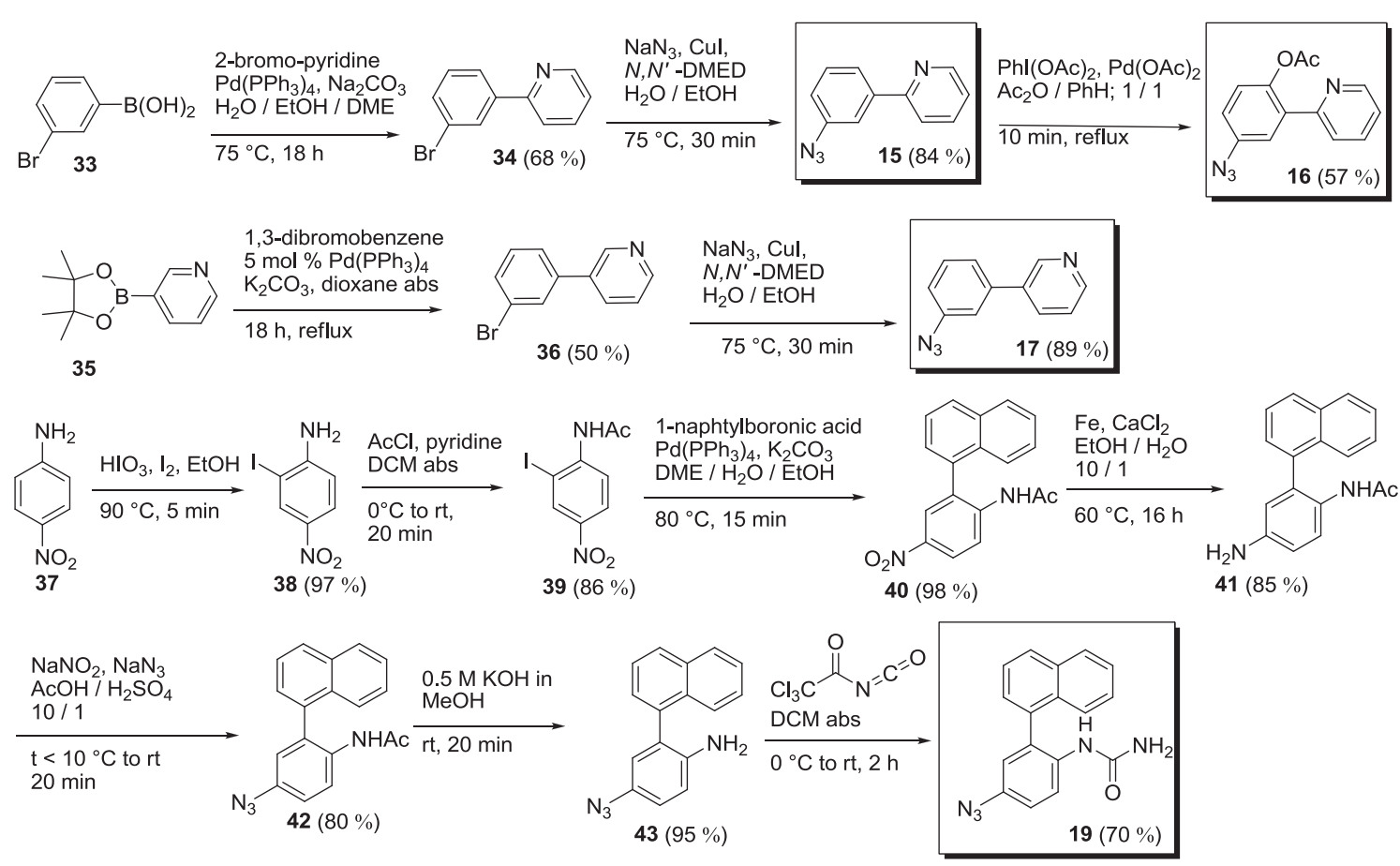

Scheme 5. Synthesis of azides $\mathbf{1 5 - 1 7}$ and $\mathbf{1 9}$.

isocyanate in dry dichloromethane followed by basic treatment [63] (Scheme 5).

Preparation of azides $\mathbf{1 8}$ and $\mathbf{2 1}$ following the same pathway proved to be unsuccessful with exception of $\mathbf{1 8 b}$ that was prepared in $44 \%$ yield over two steps (Scheme 6).

Biarylic bromophenols $\mathbf{4 6 a}, \mathbf{b}$ were obtained by coupling reaction of pinacolboronic ester 35 with protected iodophenols 44a,b, prepared from para-bromoanisol respectively in one (98\% yield) or three steps ( $87 \%$ overall yield), and subsequent deprotection of the resulted phenol ethers 45a,b in 23 and 49\% two step yield, respectively. Unfortunately zwitterionic bromophenol 46 was insoluble and its transformation into the azide $\mathbf{1 8}$ was impossible.
For this reason we decided to perform the Huisgen cycloaddition prior HO- deprotection step in order to prepare triazole T5 (Scheme 8). Methoxymethyl protected phenol $\mathbf{1 8 b}$ was obtained in $44 \%$ yield through two steps from $\mathbf{4 4 b}$ (Scheme 6). Preparation of pyrrole boronic ester $\mathbf{4 8}$ from commercially available 3-bromo-N-triisopropylsilylpyrrole $\mathbf{4 7}$ has been performed using pinacolborane in the presence of a catalytic amount of bis(acetonitrile)palladium dichloride and S-Phos (dicyclohexyl(2',6'-dimethoxybiphenyl-2-yl) phosphine) [64]. The Suzuki-Miyaura cross coupling $[63,65,66]$ between 48 and the dihalogenated phenol 49 led only to $16 \%$ yield of biarylic compound $\mathbf{5 0}$ (Scheme 6). This low yield led us to consider another pathway and to perform the coupling reaction
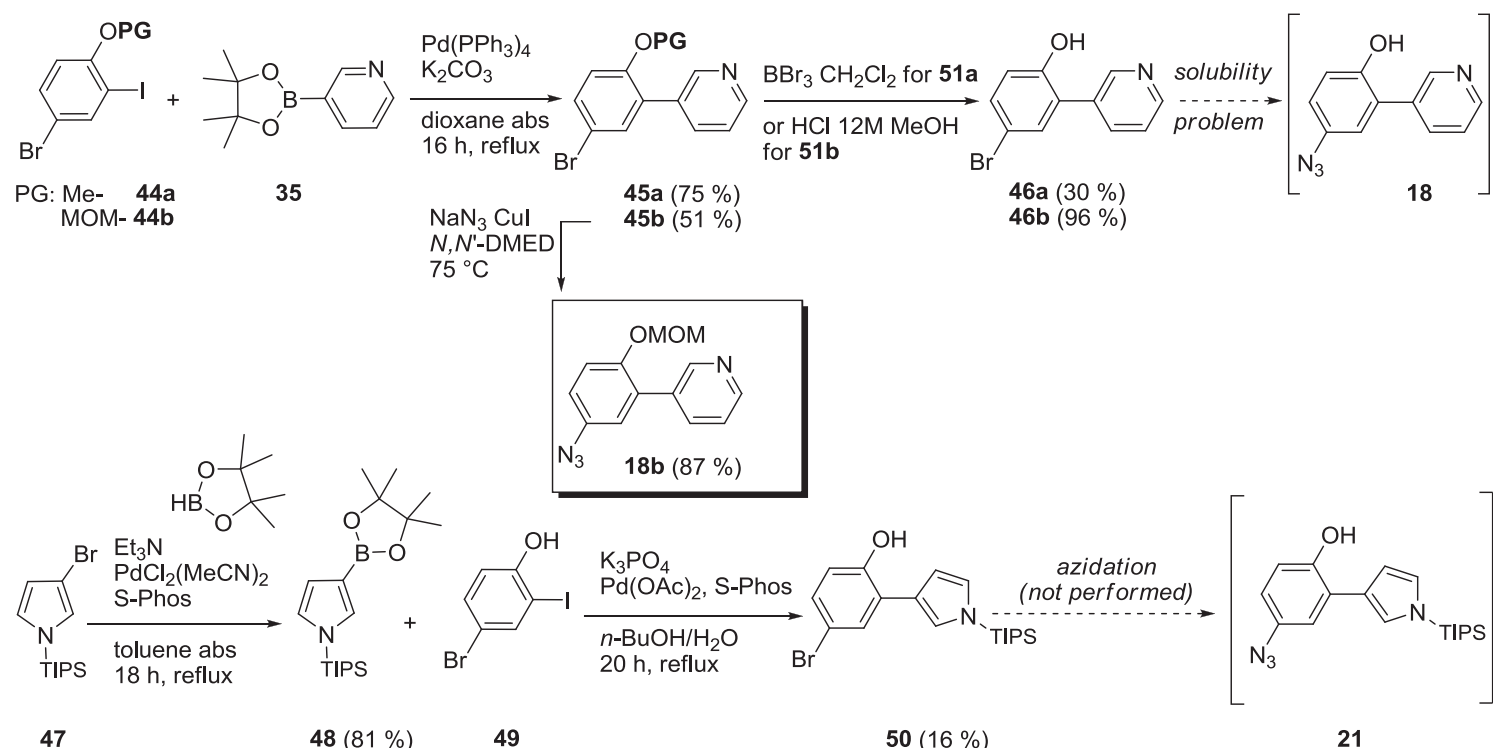

Scheme 6. Attempts for the synthesis of azides $\mathbf{1 8}$ and $\mathbf{2 1 .}$ Preparation of $\mathbf{1 8 b}$. 


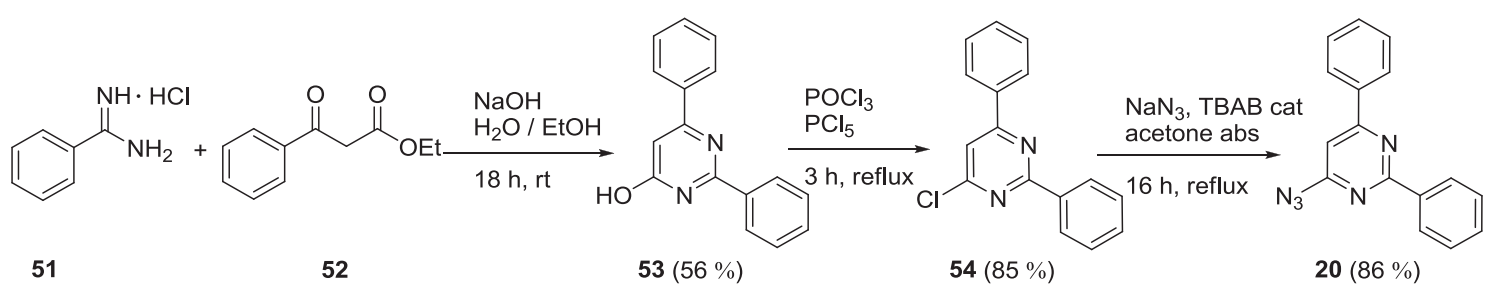

Scheme 7. Preparation of pyrimidine azide $\mathbf{2 0}$

after the Click cycloaddition in order to prepare triazole T1 (Scheme 11).

The pyrimidine azide $\mathbf{2 0}$ was prepared through pyrimidine core construction in $41 \%$ yield over three steps. Compound 53 was obtained from condensation of benzamidine hydrochloride 51 with $\beta$ ketoester 52 in 56\% yield according to the literature [67] (Scheme 7). Treatment of 53 in refluxing $\mathrm{POCl}_{3}$ and $\mathrm{PCl}_{5}$ within $3 \mathrm{~h}$ delivered $\mathbf{5 4}$ in $85 \%$ yield. Transformation of chloride $\mathbf{5 4}$ to azide $\mathbf{2 0}$ was performed using sodium azide and catalytic amount of tetra- $n$ - butylammonium bromide (TBAB) [68] (Scheme 7).

\subsubsection{Click reactions and preparation of target compounds}

We tried to perform the synthesis of predicted 1,2,3-triazoles T2

- T7 via cycloaddition between azides 15-20 and ynamide 22a

(Scheme 8). The Click chemistry concept was introduced by Sharpless and co-workers in 2001 [69,70]. All Click reactions were performed under mild conditions using in situ prepared catalytic amount of copper(I) to control the 1,4-regioselectivity (5 mol \%
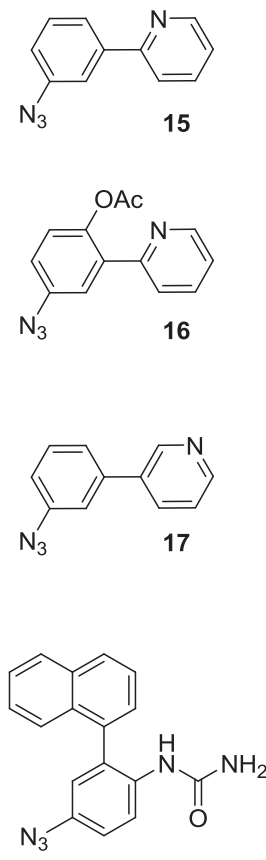

19<smiles>Nc1cc(-c2ccccc2)nc(-c2ccccc2)n1</smiles>

20

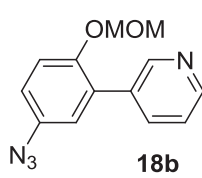

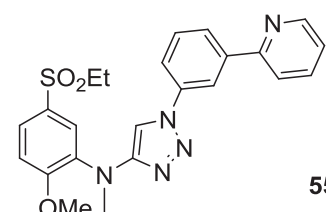

55 a $(83 \%)$

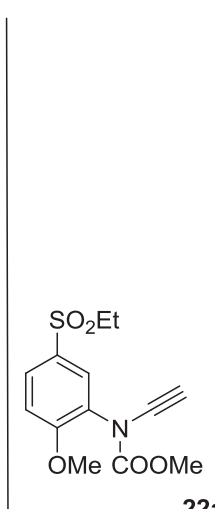

$22 a$<smiles>CCOc1ccc(OC)c(N(C)c2cn(-c3ccc(OC(C)=O)c(-c4ccccn4)c3)nn2)c1</smiles>

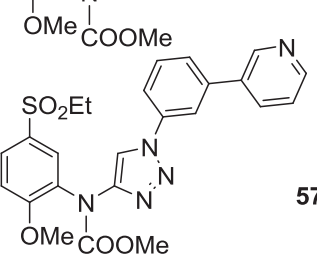

$57 a(68 \%)$

$\mathrm{CuSO}_{4} \cdot 5 \mathrm{H}_{2} \mathrm{O}$ sodium ascorbate

$t-\mathrm{BuOH} / \mathrm{H}_{2} \mathrm{O} ; 1 / 1$<smiles>CCOS(=O)(=O)OCC</smiles><smiles>C=C(/C=C(\C)c1cccc2ccccc12)N(N)/C=C(\N)NCOC</smiles>

58 a $(89 \%)$

$\mathrm{OMe}_{\mathrm{COOMe}}$<smiles>C=CNC(N)=O</smiles><smiles>CCOc1ccc(OC)c(N(C(C)=O)c2cc(-c3ccccc3)nc(-c3ccccc3)n2)c1</smiles>

$59 a(92 \%)$

an unseparable mixture of products
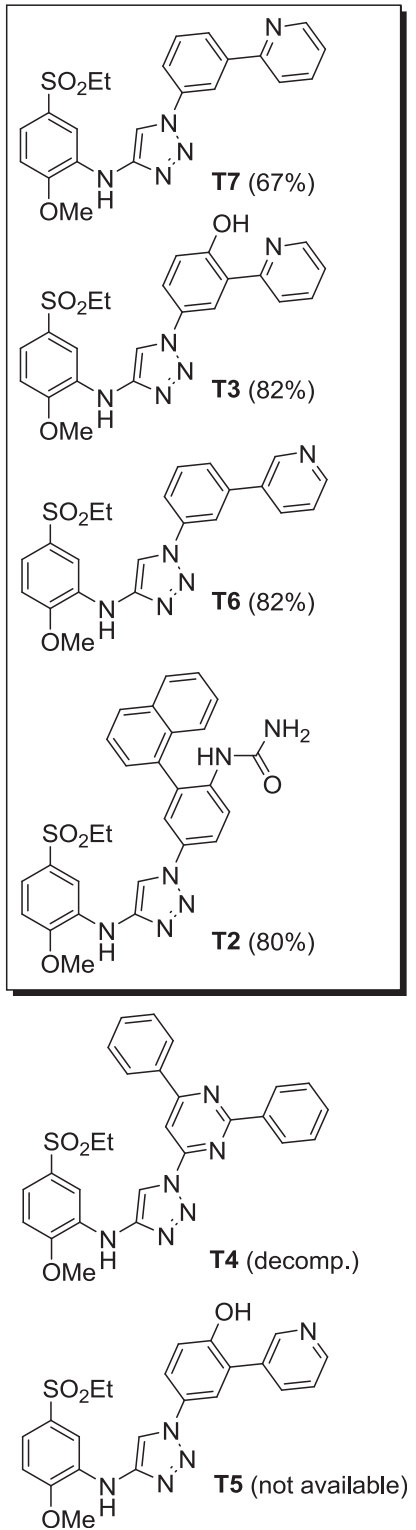

Scheme 8. Preparation of target molecules T2, T3, T6 and T7 via Click chemistry approach. 


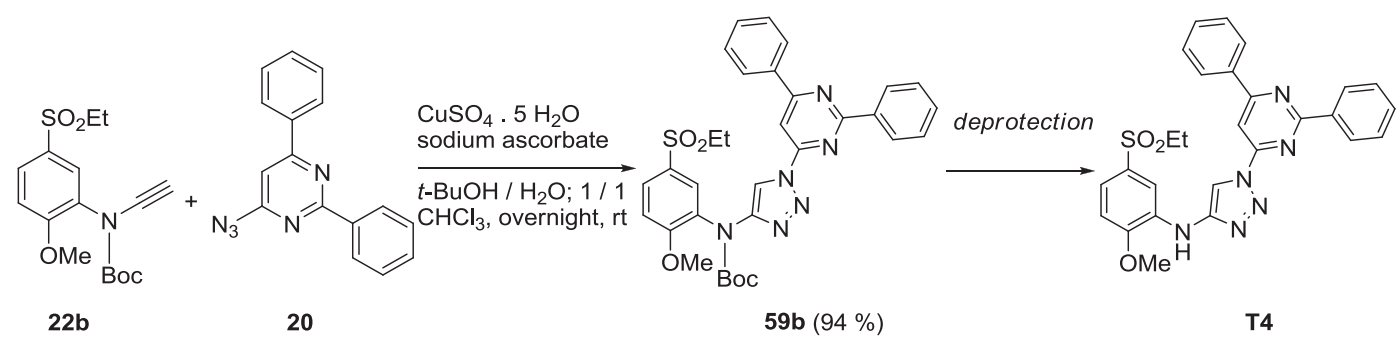

Scheme 9. Synthesis of T4 via deprotection of $\mathbf{5 9 b}$.

$\mathrm{CuSO}_{4} \cdot 5 \mathrm{H}_{2} \mathrm{O} / 10 \mathrm{~mol} \%$ sodium ascorbate) in a mixture of solvents $\left(t-\mathrm{BuOH} / \mathrm{H}_{2} \mathrm{O} / \mathrm{CHCl}_{3}\right)$ at room temperature. Deprotection of the resulting methyl carbamates $\mathbf{5 5 a}-\mathbf{5 9 a}$ was performed in $1 \mathrm{M}$ methanolic solution of $\mathrm{KOH}$ to give triazoles T2, T3, T6, T7 in good yields (67-82\%). Unfortunately pyrimidine triazole T4 was unstable in these conditions and only decomposition products were observed. Cycloaddition of $\mathbf{1 8 b}$ with $\mathbf{2 2 a}$ and its crude mixture deprotection resulted in a mixture of products containing the expected triazole $\mathbf{T 5}$ which was impossible to isolate (Scheme 8).

In order to get pyrimidine triazole $\mathbf{T 4}$, different conditions for deprotection of 59a have been tested (1 M KOH in $\mathrm{MeOH}$ or $0.5 \mathrm{M}$ $\mathrm{KOH}$ ethylene glycol both at rt or by reflux) and gave only products of decomposition. In order to circumvent these difficulties we prepared also $\mathrm{N}$-Boc protected triazole 59b by Click reaction of ynamide 22b and azide $\mathbf{2 0}$. Then we tried different conditions for deprotection of cycloadduct 59b (Scheme 9) and found that $12 \mathrm{M}$ $\mathrm{HCl}$ in EA or TFA in THF led to T4 with 80 and $90 \%$ conversion [71,72] (Scheme 9). Unfortunately, we were unable to isolate the pure triazole $\mathbf{T 4}$ in reasonable amounts as it was unstable on silica or alumina gel. Trituration or crystallization of the crude mixture was also unsuccessful in our hands.

Since the preparation of azide $\mathbf{1 8}$ failed due to the high insolubility of its precursor $\mathbf{4 6}$ (Scheme 6), we tried a Suzuki-Miyaura coupling between triazole derivative $\mathbf{6 0}$ and pinacol boronic ester 35 [54] or the boronic acid $\mathbf{6 1}[73,74]$ but also in these cases only insoluble material has been obtained (Scheme 10).

Finally, the triazole $\mathbf{T 1}$ has been prepared by the Click reaction prior to the biaryl formation (Scheme 11). The synthesis started with the preparation of the functionalized azides 65 and 68 by nitration of $o$-iodo phenol $\mathbf{6 2}$ using a 70\% solution of nitric acid giving nitrophenol 63. Part of $\mathbf{6 3}$ was acetylated to ester $\mathbf{6 6}$ and a subsequent reduction of both nitro compounds $\mathbf{6 3}$ and $\mathbf{6 6}$ using $\mathrm{SnCl}_{2}$ provided anilines $\mathbf{6 4}$ and 67, resp. [75] that were transformed into azides 65 and 68 by diazotation and reaction with $\mathrm{NaN}_{3}$. Cycloaddition between ynamide 22a and azides 65 or $\mathbf{6 8}$ using the Click chemistry conditions furnished triazole derivatives $\mathbf{6 9}$ or $\mathbf{7 0}$ in 80 and $92 \%$ yield respectively. The latters were submitted to Suzuki-Miyaura coupling with pinacolboronic ester $\mathbf{5 4}$ to afford $\mathrm{N}$ protected triazole 71. Compound $\mathbf{7 1}$ was deprotected under basic conditions to give triazole $\mathbf{T 1}$ in 5\% yield over 6 steps (via azide $\mathbf{6 5}$ ) or $8 \%$ yield over 7 steps (via azide 68 ) both started from 2iodophenol $\mathbf{6 2}$ (Scheme 11).

\subsection{Inhibition of VEGFR2 TK activity}

Prepared compounds T1-T3 and T6-T7 were screened on their ability to inhibit VEGFR2 kinase activity. Their $\mathrm{IC}_{50}$ values were determined by radiometric protein kinase assay in 10 semilogarithmic concentrations [25]. Compounds T1, T3 and T7 bind specifically to VEGFR2 tyrosine kinase and resulting typical concentration dependent enzymatic activity sigmoid curves. (e.g. Fig. 9).

The structures of AAZ and 1,2,3-triazoles T1 - T7 together with their docking score [76] and obtained biological activity ( $\mathrm{IC}_{50}$ VEGFR2 TK) are depicted on Fig. 10.

The compounds T1-T3, T6-T7 exhibited different inhibitory properties: from inactive compounds $\mathbf{T 2}$ and $\mathbf{T 6}\left(\mathrm{IC}_{50}>1 \mathrm{E}-4 \mathrm{M}\right)$, through weakly active $\mathrm{T7}, \mathrm{T1}\left(\mathrm{IC}_{50}: 42\right.$ and $40 \mu \mathrm{M}$, resp.) to moderately active inhibitor T3 $\left(\mathrm{IC}_{50}: 6.96 \mu \mathrm{M}\right)$. Triazole compounds T1-T3 and T6-T7 possess the same pharmacophoric 5-(ethylsulfonyl)-2-methoxyphenylamine moiety therefore the observed activities are dependent on the remaining aryltriazole fragments.

\subsection{Re-docking experiments}

In initially performed docking experiments (an older DOCK software) triazoles T2-T6 showed better or similar scores as their oxazole precursor AAZ (vide supra, see part 2.2 In Silico predictions). These results do not correlate well with obtained $\mathrm{IC}_{50}$ activities determined from the biological assay. Therefore an additional docking experiment was performed with newer version of the docking software (DOCK 3.6) on more calibration reliable VEGFR2 kinase taken from PDB: 1Y6B [76]. By these conditions all triazole structures although still retaining AAZ-like pose in VEGFR2 TK, showed worse score values compared to their oxazole analogue AAZ (Figs. 10 and 11).

A similar result, disfavouring 1,2,3-triazoles compare to oxazoles, was obtained from docking experiment of isosteric pairs

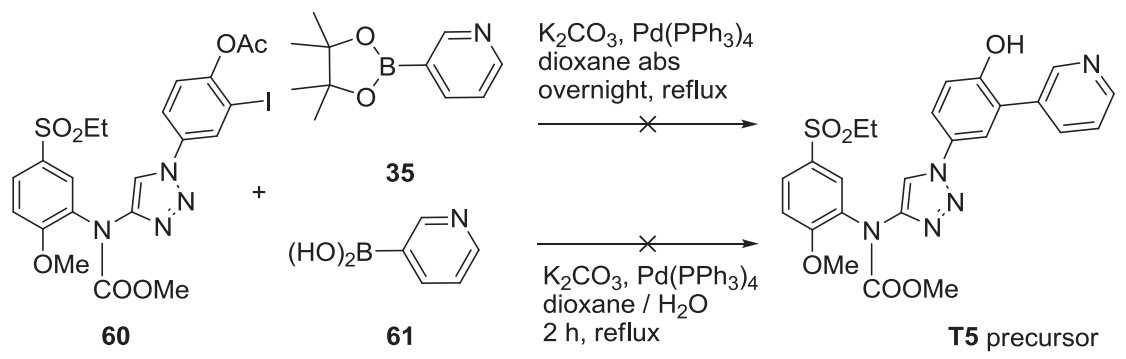

Scheme 10. Attempts for the preparation of $\mathbf{T 5}$ precursor. 

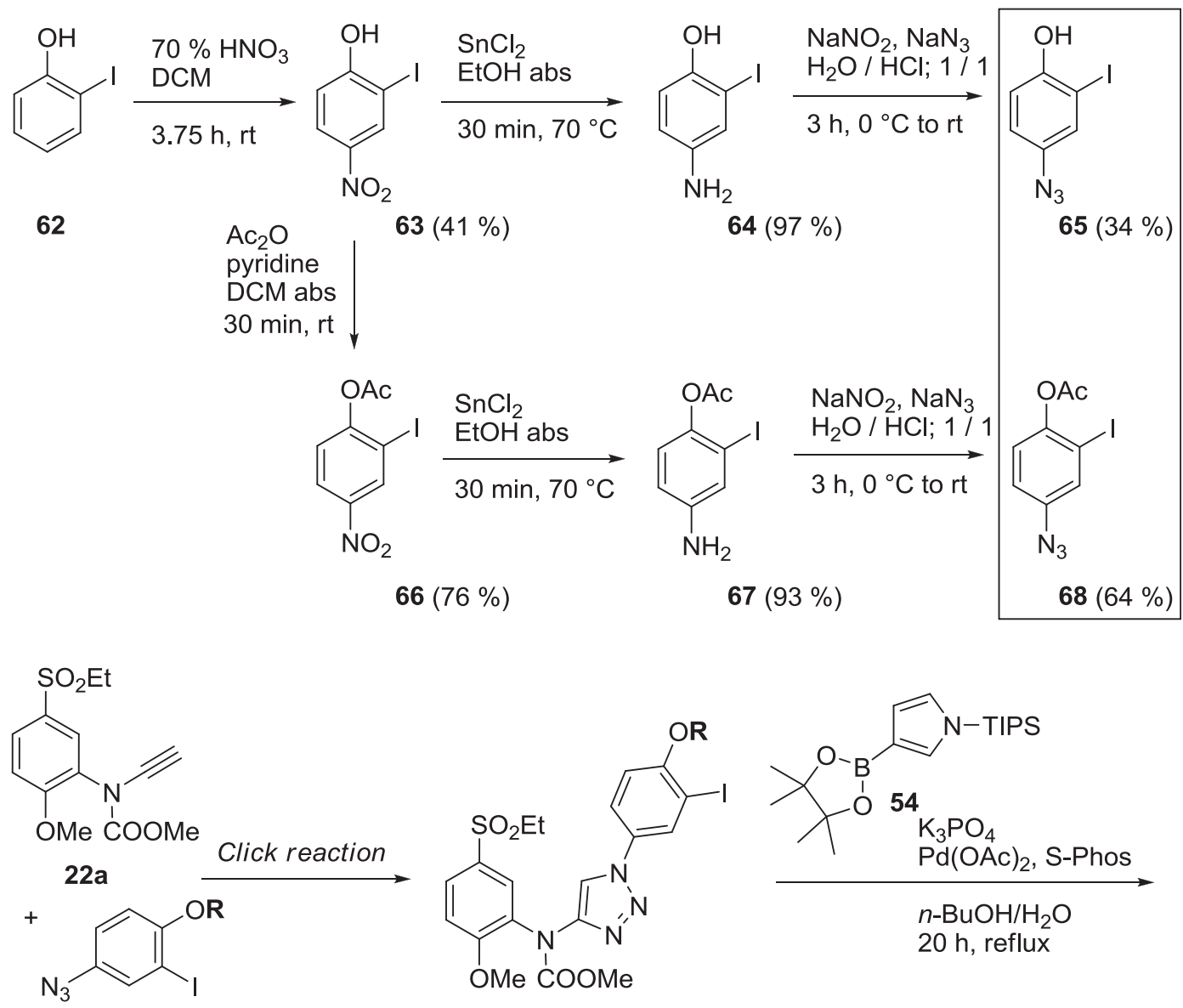<smiles>[R]Oc1ccc(-n2cc(N(C(C)=O)c3cc(S(=O)(=O)OCC)ccc3OC)nn2)cc1I</smiles>

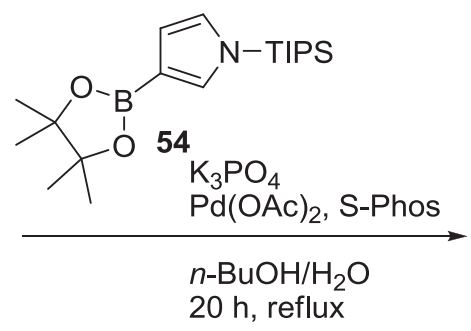

$$
\begin{aligned}
& \mathbf{R}=\mathrm{H} \quad 65 \\
& \text { Ac } 68
\end{aligned}
$$$$
\begin{array}{r}
\mathbf{R}=\text { H } 69(80 \%) \\
\text { Ac } 70(92 \%)
\end{array}
$$<smiles>CCOS(=O)(=O)c1ccc(OC)c(N(C(=O)OC)c2cn(-c3ccc(O)c(-c4ccn(C(C)(C)C)c4)c3)nn2)c1</smiles><smiles>CCOS(=O)(=O)c1ccc(OC)c(Nc2cn(-c3ccc(O)c(-c4cc[nH]c4)c3)nn2)c1</smiles>

Scheme 11. Synthesis of triazole $\mathbf{T 1}$ from iodophenol 62 .

derived from T1-T7 (values not shown).

Predicted VEGFR2 TK interactions of the most active 1,2,3triazole $\mathbf{T 3}$ and its oxazole bioisostere T3-ox are depicted on Fig. 12. The activity of T3-ox inhibitor ( IC $_{50}: 12.8 \mathrm{nM}$, VEGFR2 TK) was published by us recently [77].

\subsection{Influence of isosteric oxazole/triazole replacement}

The above re-docking experiment of 1,2,3-triazoles T1 - T7 resulted lower score than that obtained for their oxazole analogues. Triazoles T3 and T7 exhibit much less inhibitory activity against VEGFR2 kinase compared to their known oxazole bioisosters T3-ox and AAZ (T3/T3-ox, IC 50 : $6950 \mathrm{nM} / 12.8 \mathrm{nM}$ and T7/AAZ, $\mathrm{IC}_{50}$ : $42400 \mathrm{nM} / 22 \mathrm{nM}$ ). Therefore we proposed that different electronic properties of oxazole/triazole core (the size and dipole moment orientation) could be responsible for disfavouring of 1,2,3-triazole derivatives in VEGFR2 TK AAZ binding site. The structures and dipole moments depicted on Fig. 13 were performed by Discovery Studio 3.5 Visualizer [78].

VEGFR2 kinase surrounds the oxazole core of AAZ ligand (PDB: 1Y6A) by seven nonpolar amino acid residues: Phe916, Val914, Val897, Ala864, Leu838, Leu1033, and Cys917. This lipophilic pocket is less favourable to accommodate more polar 1,2,3-triazole ring. Therefore triazoles T1-T7 are less suitable to inhibit VEGFR2 kinase compare to their bioisosteric oxazole analogues.

\subsection{Cytotoxic activity of triazoles on hepatocellular carcinoma cell} lines

Four of developed 1,4-triazole compounds T1-T3 and T6 were 


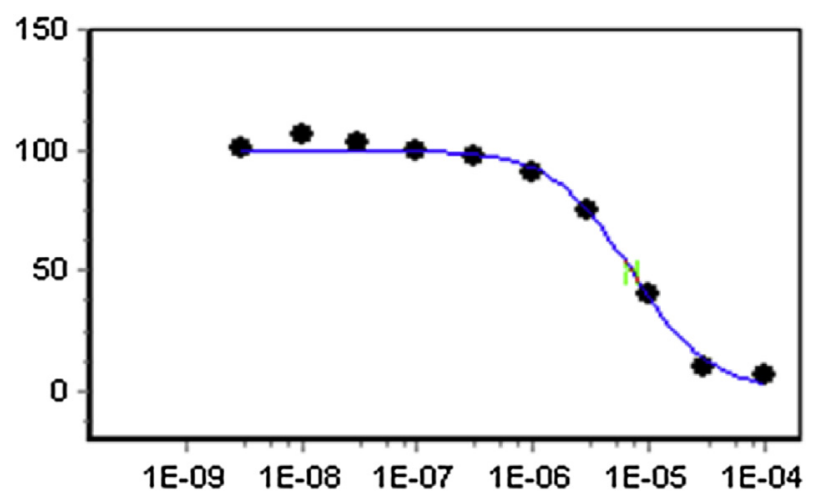

Fig. 9. An example of diminishing VEGFR2 TK activity (y axis, \%) by increasing concentration of triazole $\mathbf{T} 3$ (x axis, logarithmic scale) and determining $\mathbf{T} 3$ activity $\left(\mathrm{IC}_{50}\right.$ : $6.96 \mu \mathrm{M})$.

screened on their cytotoxic activity against well and poorlydifferentiated aggressive human hepatocellular carcinoma cell lines (Huh-7 and Mahlavu). Huh-7 is a well-differentiated (epithelial-like) hepatocellular carcinoma cell line commonly used studying liver cancer potential therapies. Huh7 expresses mutated but functional p53 protein. Mahlavu is a poorlydifferentiated (mesenchymal-like) hepatocellular carcinoma cell line. This cell line is associated with the loss of PTEN protein expression leading to the constitutive activation of PI3K/Akt pathway involved in cell survival and anti-apoptotic signalling. Comparative analysis of both cell lines with lower $\mathrm{IC}_{50}$ values for Mahlavu cells are preferred for the reason that the inhibitor may acts on its hyperactive PI3K/Akt pathway. Additionally selective inhibitor can be further analysed for its possible specific target in PI3K/Akt pathway.

Results indicate that three of four tested triazole molecules were able to inhibit growth of both tumour cell lines by half in indicated concentrations. (Table 1 ).

All triazoles $\mathbf{T 1}-\mathbf{T} 3$ and $\mathbf{T 6}$ display lover $\mathrm{IC}_{50}$ values in mesenchymal-like Mahlavu cells. Even though no enzymatic modulation of T2 on VEGFR2 TK was obtained, triazole T2 is highly selective inhibitor of growth of Mahlavu cells. The mechanism of its action as possible inhibitor of PI3K/Akt pathway could be further investigated at molecular level.

\section{Conclusions}

Seven 1,2,3-triazole compounds T1-T7 derived from oxazole VEGFR2 TK inhibitor AAZ were designed. A methodology for the synthesis of the pharmacophoric ynamides 22a,b was developed. Ynamide 22a was used as a joined precursor for the synthesis of all proposed compounds $\mathbf{T 1}-\mathbf{T 7}$. $\mathrm{Cu}(\mathrm{I})$ catalyzed Click reaction performed from 22a with different azides (yields: 68-92 \%) confirmed the synthetic reliability of this still "exotic" ynamide reagent. Five triazole compounds T1-T3, T6-T7 were prepared (Schemes 8 and 11 ) and screened in the radiometric VEGFR2 kinase assay. Within concentration limits of used biological test, two compounds T2, T6 showed to be inactive $\left(\mathrm{IC}_{50}>1 \mathrm{E}-4 \mathrm{M}\right.$ ) and other three triazoles modulate VEGFR2 tyrosine kinase activity: T7 $\left(\mathrm{IC}_{50}: 42.0 \mu \mathrm{M}\right)$, T1 (IC $50: 40.1 \mu \mathrm{M}$ ) and T3 (IC $50: 6.96 \mu \mathrm{M}$ ). (Fig. 10) The activities of new compounds were significantly lower than the ones obtained for their oxazole bioisosters (e.g. T3/T3-ox in Fig. 12 and T7/AAZ in Fig. 10, resp.). Despite the diminished activity, the triazole modulators T1, T3 and T7 inhibit VEGFR2 kinase by concentration dependent manner. Concerning the identical substructure, the inhibitory activity of 1,4-triazoles T1-T3, T6-T7 is depending on the decoration of their aryl part joined to $\mathrm{N}(1)$ of the triazole core. (Fig. 1) The different electronic properties of 1,2,3-triazole and oxazole fragments (size and orientation of the dipole moments, Fig. 13) were proposed to be responsible for low activities of triazoles T1-T3, T6-T7. The more polar triazole core binds less readily into VEGFR2 TK lipophilic oxazole binding pocket known

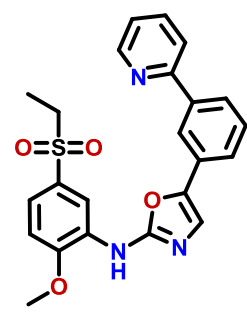

AAZ docking score $-50.3(-51.6)$ $\mathrm{IC}_{50}=22 \mathrm{nM}$ (VEGFR2 TK)

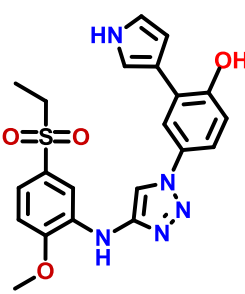

T1

$-46.7(-45.8)$

$\mathrm{IC}_{50}=40100 \mathrm{nM}$

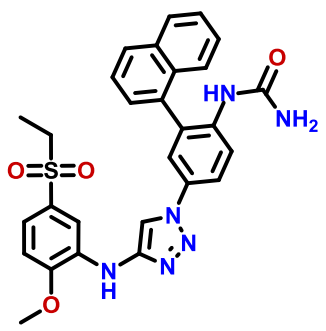

T2

$-46.6(-52.3)$

$\mathrm{IC}_{50}>1 \mathrm{E}-4 \mathrm{M}$

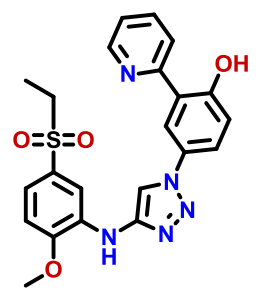

T3

$-40.6(-44.7)$

$\mathrm{IC}_{50}=6960 \mathrm{nM}$
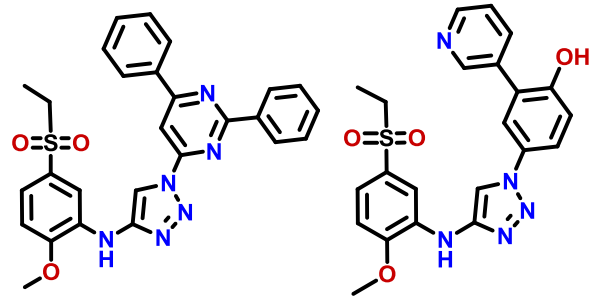

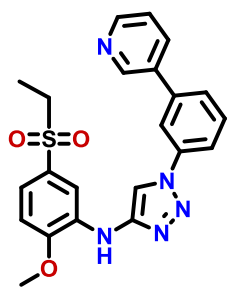

T6

$-39.0(-36.1)$

${ } \mathrm{C}_{50}>1 \mathrm{E}-4 \mathrm{M}$<smiles>CCS(=O)(=O)c1ccc(OC)c(Nc2cn(-c3cccc(-c4ccccn4)c3)nn2)c1</smiles>

T7

$-38.9(-37.5)$

$\mathrm{IC}_{50}=42000 \mathrm{nM}$

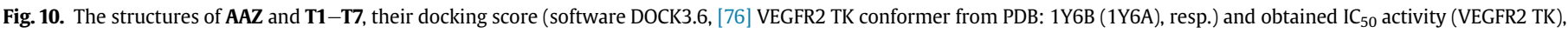
if not otherwise stated. NA: the compound was not available. 


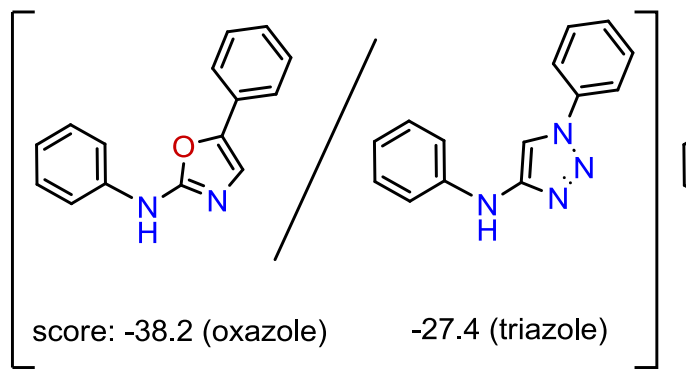

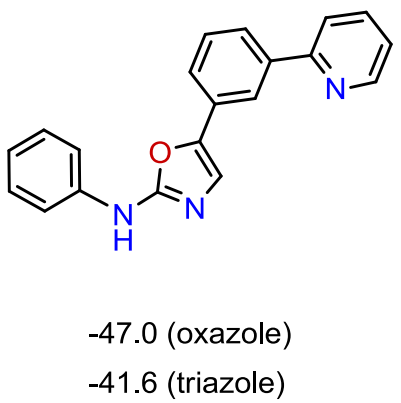<smiles>CCS(=O)(=O)c1ccc(OC)c(Nc2ncc(C)o2)c1</smiles><smiles>CCS(=O)(=O)c1ccc(OC)c(Nc2ncc(-c3ccccc3)o2)c1</smiles><smiles>CCS(=O)(=O)c1ccc(OC)c(Nc2ncc(-c3cccc(-c4ccccn4)c3)o2)c1</smiles>

-37.7 (oxazole)

-44.6 (oxazole) -31.6 (triazole) -34.2 (triazole)

\section{-50.3 (oxazole, AAZ)} -38.9 (triazole)

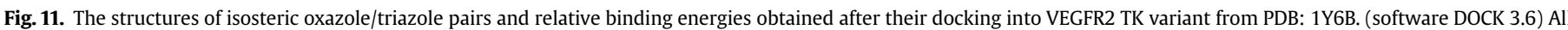
depicted structures are predicted to occupy AAZ-like binding site in VEGFR2 kinase.
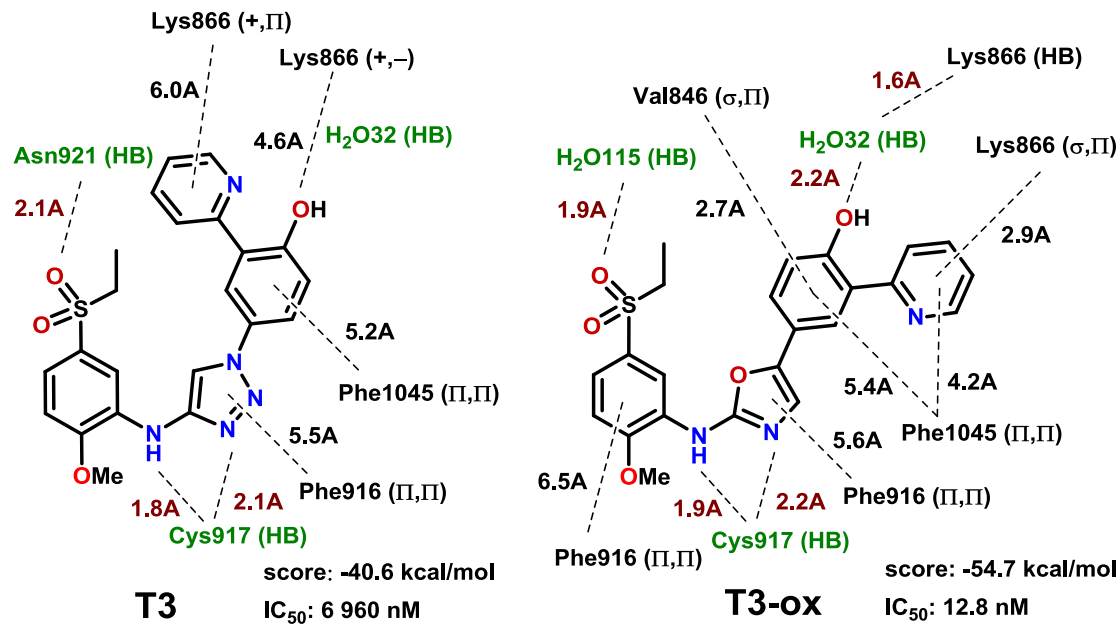

Fig. 12. The structures, docking scores, $\mathrm{IC}_{50}$ activities, predicted conformations and interactions (DOCK 3.6) of T3 and T3-ox isosteres,

from PDB: 1Y6A or 1Y6B. We can conclude that the 1,2,3-triazole compounds T1, T3 and T7 are weaker VEGFR2 inhibitors than their oxazole analogues.

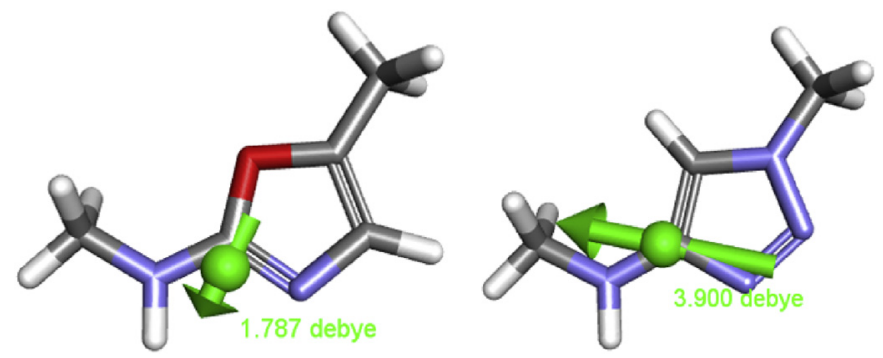

Fig. 13. Calculated dipole moment (value and orientation) for simplified N,5dimethyloxazol-2-amine (left structure) and its 1,2,3-triazole isostere in the right.
In addition T1-T3 and T6 were screened on their cytotoxic activity against two human hepatocellular carcinoma cell lines (Huh7 and Mahlavu). Mahlavu is aggressive hepatocellular carcinoma

Table 1

IC 50 growth inhibition values of compounds T1-T3 and T6 in Huh7 and Mahlavu human cancer hepatocellular cell lines.

\begin{tabular}{lll}
\hline \multirow{2}{*}{ Compound } & Tumour cell lines $\mathrm{IC}_{50}[\mathrm{uM}]$ & \\
\cline { 2 - 3 } & Huh7 & Mahlavu \\
\hline T6 & 12.8 & 11.8 \\
T1 & 18.6 & 11.9 \\
T3 & 17.7 & 13.8 \\
T2 & NA $^{\mathrm{a}}$ & 27.9 \\
\hline
\end{tabular}

Data in the table are sorted according to activity against aggressive Mahlavu tumor cells.

a NA: not active. 


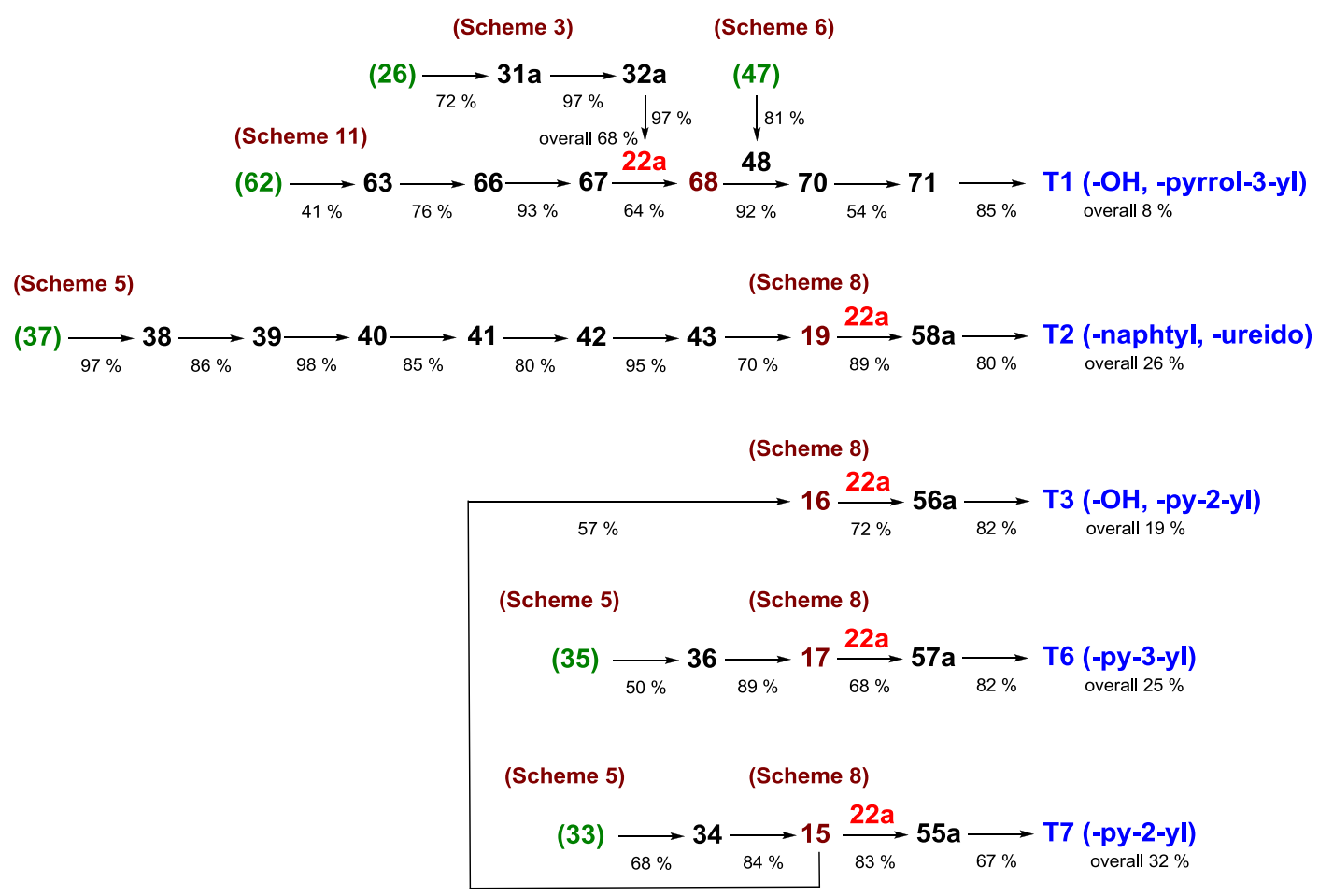

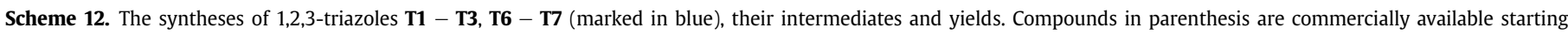

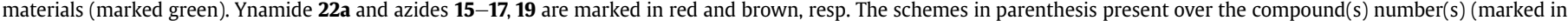

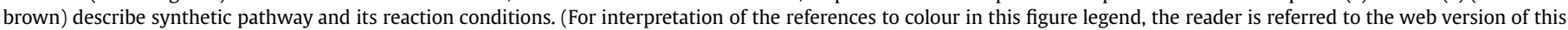
article.)

with constitutive active PI3K/Akt anti-apoptotic signalling. All screened triazole compounds performed low IC $_{50}$ activity (12-28 uM) against Mahlavu cells (Table 1). Even though compounds T6 and T2 were not active in VEGFR TK assay, both of them showed interesting cytotoxic activity against Mahlavu carcinoma. The high selectivity of triazole T2 to Mahlavu over Huh-7 cell lines indicates its possible affinity to PI3K/Akt pathway that can be further investigated.

\section{Experimental}

\subsection{Molecular docking}

Docking experiments were accomplished according the expert self-assessing system DOCK Blaster (University of California, San Francisco) described in the literature [79]. The calculations were performed by an older DOCK version and later on with the DOCK 3.6 version of UCSF DOCK software $[33,76]$.

\subsection{Chemistry}

All reactions and compounds leading to prepared 1,2,3-triazole products $\mathbf{T 1}-\mathbf{T 3}, \mathbf{T 6}$ and $\mathbf{T 7}$ are completely described in Supplementary Material in order as they are depicted in the Scheme 12. Beside other compound characteristics the Supplementary material contains also ${ }^{1} \mathrm{H}$ and ${ }^{13} \mathrm{C}$ NMR spectral graphical abstracts.

For simplicity, only the synthetic pathway leading to the most active triazole $\mathbf{T} \mathbf{3}$ is described here (Scheme 13).

\subsubsection{General procedures}

THF and $\mathrm{Et}_{2} \mathrm{O}$ were dried over and distilled from Na/benzophenone under $\mathrm{Ar}$ atmosphere. DCM and $\mathrm{Et}_{3} \mathrm{~N}$ were dried over calcium hydride or $\mathrm{KOH}$ pellets, resp. and distilled. Commercially available chemicals and solvents were purchased from Sigma-Aldrich company and were used without further purification. The course of the reactions was followed by TLC analysis (Merck Silica gel $60 \mathrm{~F}_{254}$ ). UV lamp ( $254 \mathrm{~nm}$ ) and iodine vapours were used for visualization of TLC spots. Flash column chromatography was performed on silica gel (40-60 mesh). Melting points were determined on a Büchi B-540 apparatus (Büchi Labortechnik, Flawil, Switzerland) and were uncorrected. All ${ }^{1} \mathrm{H}-\mathrm{NMR}$ and ${ }^{13} \mathrm{C}-\mathrm{NMR}$ spectra were recorded on Brucker instruments $(500,300 \mathrm{MHz}$ for hydrogen and $100 \mathrm{MHz}$ for carbon, Brucker Bioscience, Billerica, MA, USA) with $\mathrm{CDCl}_{3}$, DMSO- $d_{6}$ or acetone- $d_{6}$ as solvent. Chemical shifts are given in parts per million (ppm). IR spectra were acquired on FT-IR-ATR REACT IR 1000 (ASI Applied Systems) with diamond probe and MTS detector. ESI Mass spectral data were obtained by Esquire-LC-00075 spectrometer (Brucker Bioscience). Other mass spectra were performed on LC-MS (Agilent Technologies 1200 Series equipped with Mass spectrometer Agilent Technologies 6100 Quadrupole LC-MS). Elemental analyses for carbon, hydrogen and nitrogen were performed with an Eager 300 analyzer. Used abbreviations: EA: ethyl acetate, Boc: tertbutyloxycarbonate, Cy: cyclohexane, DCM: dichloromethane, EWG: electron withdrawing group (e.g. -COOMe, -Boc, -Ts etc.), FLC: Flash liquid chromatography, $N, N^{\prime}$-DMED: $N, N$-dimethylethylenediamine, RT: room temperature, S-Phos: 2-dicyclohexylphosphino- $2^{\prime}, 6^{\prime}$ dimethoxybiphenyl [CAS 657408-07-6], TIPS: triisopropylsilyl, TLC: thin layer chromatography $\left(\mathrm{SiO}_{2} / \mathrm{UV}_{254}\right)$. Elemental analyses indicated in the experimental part by the symbols of the elements were within $\pm 0.4 \%$ of the theoretical values.

4.2.1.1. A: N-alkynylation of protected anilnies with bromoalkyne $\mathbf{2 9}$ (Skydrup's protocol). 1-Bromoalkyne (1.1 mol eq) 29 (1.0 M solution in toluene) was added to a mixture of an amide $(1.0 \mathrm{~mol} \mathrm{eq})$ (EWG protected aniline) $31 \mathrm{a}-\mathbf{c},\left(3.0 \mathrm{~mol}\right.$ eq) $\mathrm{K}_{3} \mathrm{PO}_{4}$, (0.2 mol eq) 


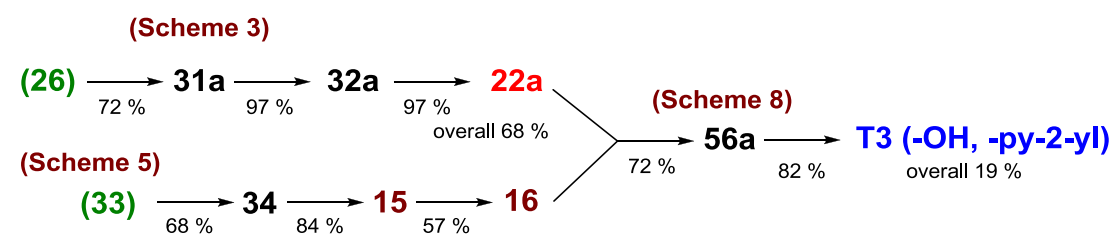

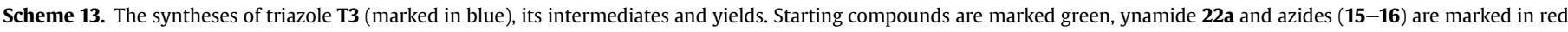
and brown, resp. (For interpretation of the references to colour in this figure legend, the reader is referred to the web version of this article.)

$\mathrm{CuSO}_{4} \cdot 5 \mathrm{H}_{2} \mathrm{O}$ and $(0.4 \mathrm{~mol}$ eq) 1,10 -phenantroline. The reaction mixture was heated at $65-75{ }^{\circ} \mathrm{C}$ (oil bath temperature) for $20 \mathrm{~h}$. Upon completion, detected by TLC, the reaction mixture was cooled to RT, diluted with EA, filtered through Celite and the filtrate concentrated under reduced pressure. The crude product was purified by flash chromatography on silica gel (Scheme 3).

4.2.1.2. B: TIPS group deprotection. A (1.0 mol eq) $1.0 \mathrm{M}$ solution of TBAF in THF was added dropwise to a solution of TIPS protected ynamide (1.0 mol eq) 32a-b in dry THF. After 5 min stirring at RT, the volatile parts were evaporated under reduced pressure. The concentrated reaction mixture was partitioned in a mixture of EA and brine (1:1). Collected organic layers were dried over anhydrous $\mathrm{MgSO}_{4}$, filtered and evaporated leading to a desired product (Scheme 3).

4.2.1.3. C: substitution of an aromatic halide to azide. The solution of ( $1.0 \mathrm{~mol}$ eq) aryl bromide, ( $2.0 \mathrm{~mol} \mathrm{eq}) \mathrm{NaN}_{3},(0.05 \mathrm{~mol}$ eq) sodium ascorbate, ( $0.1 \mathrm{~mol} \mathrm{eq}) \mathrm{Cul}$ and $(0.15 \mathrm{~mol} \mathrm{eq}) N, N^{\prime}$-DMED in $4 \mathrm{~mL}$ of mixture EtOH : $\mathrm{H}_{2} \mathrm{O}(7: 3)$ was refluxed under $\mathrm{Ar}$ atmosphere. Progress of the reaction was monitored by TLC. When the aryl bromide was completely consumed, or when the progress of the reaction had stopped, the reaction mixture was cooled to RT and the crude product purified either by extraction and/or FLC chromatography giving the desired aryl azide (Scheme 5).

4.2.1.4. D: copper-catalyzed Click chemistry reaction. Prepared ( $1.0 \mathrm{~mol} \mathrm{eq}$ ) ynamide $22 \mathrm{a}$ and $(1.0 \mathrm{~mol}$ eq) of corresponding azide were suspended in $6 \mathrm{~mL}$ of mixture tert-butanol : $\mathrm{H}_{2} \mathrm{O}(1: 1)$ and $5 \mathrm{~mL} \mathrm{CHCl}_{3}$. Consequently, premixed solution of sodium ascorbate ( $10 \mathrm{~mol} \%$ ) and $\mathrm{CuSO}_{4} \cdot 5 \mathrm{H}_{2} \mathrm{O}(5 \mathrm{~mol} \%)$ in $3 \mathrm{~mL}$ of $\mathrm{H}_{2} \mathrm{O}$ was added. After stirring overnight the reaction mixture was diluted with $10 \mathrm{~mL} \mathrm{H}_{2} \mathrm{O}$ and extracted with EA $(3 \times 10 \mathrm{~mL})$. The combined organic layers were washed with $10 \mathrm{~mL}$ of $\mathrm{NH}_{4} \mathrm{OH}$ (3\% solution in brine), treated over $\mathrm{MgSO}_{4}$, filtered, evaporated and dried in HV. Purification using FLC chromatography afforded 1,4-disubstituted 1,2,3-triazole product (Scheme 8).

4.2.1.5. E: deprotection of methoxycarbonyl group. Protected aminotriazole derivative $(2.0 \mathrm{mmol}, 1.0 \mathrm{~mol} \mathrm{eq})$ was stirred in $5 \mathrm{~mL}$ of $1 \mathrm{M}$ solution of $\mathrm{KOH}$ in $\mathrm{MeOH}$ at RT overnight. The progress of reaction was monitored by LCMS or ${ }^{1} \mathrm{H}$ NMR spectroscopy. When the reaction was accomplished, the mixture was neutralized with $1 \mathrm{M}$ $\mathrm{HCl}$ and extracted with $\mathrm{EA}(3 \times 8 \mathrm{~mL})$. The combined organic layers were washed with water, treated over $\mathrm{MgSO}_{4}$, filtered, evaporated under reduced pressure and dried with HV. Obtained crude product was purified by FLC (Scheme 8).

\subsection{Synthesis of triazole $\mathbf{T} 3(-\mathrm{OH},-p y-2-y l)$}

\subsubsection{Synthesis of methyl 5-(ethylsulfonyl)-2-}

methoxyphenylcarbamate (31a)

Pyridine $1.7 \mathrm{~mL}$ (21.2 mmol, $1.1 \mathrm{~mol} \mathrm{eq})$ was added to solution of $4.15 \mathrm{~g}$ (9.3 mmol, $1.0 \mathrm{~mol} \mathrm{eq)} \mathrm{5-(ethylsulfonyl)-2-methoxyaniline}$
(26) in $35 \mathrm{~mL}$ of dry DCM. ClCOOMe $1.6 \mathrm{~mL}$ (21.2 mmol, $1.1 \mathrm{~mol}$ eq) was added to the reaction mixture dropwise at $0{ }^{\circ} \mathrm{C}$. The mixture was stirred at RT for $2.5 \mathrm{~h}$ and consumption of starting material was confirmed by TLC. The reaction was quenched with brine $(2 \times 30 \mathrm{~mL})$ and the organic layer was separated, dried over anhydrous $\mathrm{MgSO}_{4}$ and concentrated under reduced pressure. The crude product was purified by crystallization from $\mathrm{Et}_{2} \mathrm{O}$ with charcoal to yield $3.15 \mathrm{~g}$ (13.9 mmol, 72\%) 31a in form of white crystals. M.p. $121.0-123.0{ }^{\circ} \mathrm{C}\left[\mathrm{Et}_{2} \mathrm{O}\right]$.

${ }^{1} \mathbf{H}-\mathrm{NMR}\left(300 \mathrm{MHz}, \mathrm{CDCl}_{3}\right): \delta 8.54(\mathrm{br} \mathrm{s}, 1 \mathrm{H},-\mathrm{NH}-), 7.53(\mathrm{dd}, 1 \mathrm{H}$ $J(3,4)=8.6 \mathrm{~Hz}, J(4,6)=2.3 \mathrm{~Hz}, \mathrm{H}-\mathrm{C}(4)), 7.19(\mathrm{~d}, 1 \mathrm{H}, J(4,6)=2.3 \mathrm{~Hz}$ $\mathrm{H}-\mathrm{C}(6)), 6.90(\mathrm{~d}, 1 \mathrm{H}, J(3,4)=8.6 \mathrm{~Hz}, \mathrm{H}-\mathrm{C}(3)), 3.89\left(\mathrm{~s}, 3 \mathrm{H},-\mathrm{OCH}_{3}\right)$, $3.74\left(\mathrm{~s}, 3 \mathrm{H},-\mathrm{COOCH}_{3}\right), 3.05\left(2 \mathrm{H}, \mathrm{q}, J\left(\mathrm{CH}_{2}, \mathrm{CH}_{3}\right)=7.4 \mathrm{~Hz}\right.$ $\left.-\mathrm{SO}_{2} \mathrm{CH}_{2} \mathrm{CH}_{3}\right), 1.21\left(3 \mathrm{H}, \mathrm{t}, J\left(\mathrm{CH}_{2}, \mathrm{CH}_{3}\right)=7.4 \mathrm{~Hz},-\mathrm{SO}_{2} \mathrm{CH}_{2} \mathrm{CH}_{3}\right)$.

${ }^{13} \mathrm{C}-\mathrm{NMR}\left(100 \mathrm{MHz}, \mathrm{CDCl}_{3}\right): \delta 153.6(\mathrm{~s},-\mathrm{NHCOO}-), \overline{1} 151.2$ (s, C(2)), 130.9 (d, C(4)), 128.5 (s, C(5)), 123.7 (d, C(6)), 117.6 (s, C(1)) 109.7 (d, C(3)), 56.2 (q, $\mathrm{CH}_{3} \mathrm{O}-$ ), 52.6 (t, $-\mathrm{SO}_{2} \mathrm{CH}_{2}-$ ), 50.6 (q, $\left.-\mathrm{COOCH}_{3}\right), 7.6\left(\mathrm{q},-\mathrm{CH}_{2} \mathrm{CH}_{3}\right)$.

IR $\bar{v}$ (solid): 3416, 1721, 1595, 1535, 1304, 1275, 1264, 1239, 1127 $1064,766 \mathrm{~cm}^{-1}$.

Anal. Calcd for $\mathrm{C}_{11} \mathrm{H}_{15} \mathrm{NO}_{5} \mathrm{~S}$ (273.31): $\mathrm{C}, 48.34 ; \mathrm{H}, 5.53 ; \mathrm{N}, 5.12$. Found: C, 48.30; H, 5.47; N, 5.02.

\subsubsection{Synthesis of methyl 5-(ethylsulfonyl)-2-}

methoxyphenyl((triisopropylsilyl)ethynyl)carbamate (32a)

Compound 32a was prepared according to the general procedure A. Yield: (97\%). Purification: filtration through a silica gel pad (eluent: Cy/EA, 1/1). M.p. $42.3-45.1{ }^{\circ} \mathrm{C}$ [Cy/EA], pale yellow solid.

${ }^{1} \mathbf{H}-\mathbf{N M R}\left(300 \mathrm{MHz} \mathrm{CDCl}_{3}\right): \delta 7.82(\mathrm{~d}, 1 \mathrm{H}, J(4,6)=2.3 \mathrm{~Hz}$, $\mathrm{H}-\mathrm{C}(6)), 7.81(\mathrm{dd}, 1 \mathrm{H}, J(3,4)=8.2 \mathrm{~Hz}, J(4,6)=2.3 \mathrm{~Hz}, \mathrm{H}-\mathrm{C}(4)), 7.04$ $(\mathrm{d}, 1 \mathrm{H}, J(3,4)=8.2 \mathrm{~Hz}, \mathrm{H}-\mathrm{C}(3)), 3.88\left(\mathrm{~s}, 3 \mathrm{H}, \mathrm{ArOCH}_{3}\right), 3.77(\mathrm{~s}, 3 \mathrm{H}$, $\left.-\mathrm{COOCH}_{3}\right), 3.02\left(\mathrm{q}, 2 \mathrm{H}, J\left(\mathrm{CH}_{2}, \mathrm{CH}_{3}\right)=7.5 \mathrm{~Hz},-\mathrm{SO}_{2} \mathrm{CH}_{2}-\right), 1.20(\mathrm{t}, 3 \mathrm{H}$ $\left.J\left(\mathrm{CH}_{2}, \mathrm{CH}_{3}\right)=7.5 \mathrm{~Hz},-\mathrm{SO}_{2} \mathrm{CH}_{2} \mathrm{CH}_{3}\right), 0.98\left(\right.$ br s, $21 \mathrm{H}$, all $\mathrm{CH}$ and $-\mathrm{CH}_{3}$ from TIPS: $\left.-\mathrm{Si}\left(\mathrm{CH}\left(\mathrm{CH}_{3}\right)_{2}\right)_{3}\right)$.

${ }^{13}$ C-NMR (75 MHz, CDCl 3 ): $\delta 158.6(\mathrm{~s}, \mathrm{C}(2)), 157.6(\mathrm{~s}, \mathrm{~N}(\mathrm{C}=\mathrm{O})$ ), $2 \times 130.3$ (s and d, C(4) and C(5)), 128.8 and 128.7 (s and d, C(1) and $\mathrm{C}(6)), 112.4(\mathrm{~d}, \mathrm{C}(3)), 96.2$ and $77.2(2 \times \mathrm{s}$ from $\mathrm{C} \equiv \mathrm{C}), 56.4(\mathrm{q}$, $\left.\mathrm{ArOCH}_{3}\right), 54.5$ (q, $\left.-\mathrm{COOCH}_{3}\right), 50.9\left(-\mathrm{SO}_{2} \mathrm{CH}_{2} \mathrm{CH}_{3}\right), 18.6(\mathrm{q}, 6 \times \mathrm{Me}$ from TIPS), 11.3 (d, $3 \times \mathrm{C} \overline{\mathrm{H}}$ from TIPS), $7.6\left(\mathrm{q},-\mathrm{SO}_{2} \mathrm{CH}_{2} \mathrm{CH}_{3}\right)$.

IR $v$ (solid): 2941, 2864, 2180, 1744, 1440, 1290, 1132, $730 \mathrm{~cm}^{-1}$

Anal. Calcd for $\mathrm{C}_{22} \mathrm{H}_{35} \mathrm{NO}_{5} \mathrm{SSi}$ (453.67): C, 58.24; $\mathrm{H}, 7.78 ; \mathrm{N}, 3.09$. Found: C, 58.04; H, 7.80; N, 2.91.

\subsubsection{Synthesis of methyl 5-(ethylsulfonyl)-2- methoxyphenyl(ethynyl)carbamate (22a)}

Compound 22a was prepared according to the general procedure B. Yield: 97\%. Purification: filtration through a silica gel pad (eluent: $\mathrm{Cy} / \mathrm{EA}, 1 / 2)$. M.p. $158.1-163.2{ }^{\circ} \mathrm{C}$ [Cy/EA], pale yellow solid.

${ }^{1} \mathbf{H}-N M R\left(300 \mathrm{MHz}, \mathrm{CDCl}_{3}\right): \delta 7.83(\mathrm{dd}, 1 \mathrm{H}, J(3,4)=8.5 \mathrm{~Hz}$, $J(4,6)=2.3 \mathrm{~Hz}, \mathrm{H}-\mathrm{C}(4)), 7.81(\mathrm{~d}, 1 \mathrm{H}, J(4,6)=2.3 \mathrm{~Hz}, \mathrm{H}-\mathrm{C}(6)), 7.05$ $(\mathrm{d}, 1 \mathrm{H}, J(3,4)=8.5 \mathrm{~Hz}, \mathrm{H}-\mathrm{C}(3)), 3.90\left(\mathrm{~s}, 3 \mathrm{H}, \mathrm{ArOCH}_{3}\right), 3.79(\mathrm{~s}$, $\left.3 \mathrm{H},-\mathrm{COOCH}_{3}\right), 3.04$ (q, $\left.2 \mathrm{H}, J\left(\mathrm{CH}_{2}, \mathrm{CH}_{3}\right)=7.5 \mathrm{~Hz},-\mathrm{SO}_{2} \mathrm{CH}_{2} \mathrm{CH}_{3}\right), 2.74$ $(\mathrm{s}, 1 \mathrm{H},-\mathrm{C} \equiv \mathrm{CH}), 1.23\left(\mathrm{t}, 3 \mathrm{H}, \mathrm{J}\left(\mathrm{CH}_{2}, \mathrm{CH}_{3}\right)=7.5 \mathrm{~Hz},-\mathrm{SO}_{2} \overline{\mathrm{C}}_{2} \mathrm{CH}_{3}\right)$.

${ }^{13}$ C-NMR (75 MHz, $\left.\mathrm{CDCl}_{3}\right): \delta 158.8\left(\mathrm{~s},-\mathrm{C}(=\mathrm{O}) \mathrm{OCH}_{3}\right), 1 \overline{54} .6(\mathrm{~s}$, 
$C(2)), 130.8$ and $130.6((d, C(4))$ and $(s, C(5)), 129.0(d, C(6)), 128.2$ (s, $\mathrm{C}(1)), 112.5(\mathrm{~d}, \mathrm{C}(3)), 75.8(\mathrm{~s}, \mathrm{C} \equiv \mathrm{CH}), 57.5(\mathrm{~d}, \mathrm{C} \equiv \mathrm{CH}), 56.5(\mathrm{t}$, $-\mathrm{SO}_{2} \mathrm{CH}_{2} \mathrm{CH}_{3}$ ), 54.7 (q, $\left.\operatorname{ArOCH}_{3}\right), 50.9$ (q, $\left.-\mathrm{COOCH}_{3}\right), 7.5$ (q, $\left.-\mathrm{SO}_{2} \overline{\mathrm{CH}}_{2}-\mathrm{CH}_{3}\right)$.

IR $v$ (solid): 3267, 2152, 1726, 1500, 1443, 1315, 1293, 1130, 1089, $827,730 \mathrm{~cm}^{-1}$.

Anal. Calcd for $\mathrm{C}_{13} \mathrm{H}_{15} \mathrm{NO}_{5} \mathrm{~S}$ (297.33): C, 52.51; H, 5.09; N, 4.71. Found: C, 52.62; H, 5.16; N, 4.39 .

\subsubsection{Synthesis of 2-(3-bromophenyl)pyridine (34)}

A degassed mixture of $2.4 \mathrm{~mL}$ (24.9 mmol, $1.00 \mathrm{~mol} \mathrm{eq}) 2-$ bromopyridine, $5.75 \mathrm{~g}$ (54.8 mmol, $2.20 \mathrm{~mol}$ eq) $\mathrm{Na}_{2} \mathrm{CO}_{3}$, $28 \mathrm{~mL} \mathrm{H} \mathrm{H}_{2} \mathrm{O}, 20 \mathrm{~mL}$ EtOH, $63 \mathrm{~mL} \mathrm{1,2-dimethoxyethane,} 5.0 \mathrm{~g}$ (24.9 mmol, $1.00 \mathrm{~mol} \mathrm{eq}) 3$-bromophenylboronic acid (33) and $288.0 \mathrm{mg}$ ( $0.25 \mathrm{mmol}, 0.01 \mathrm{~mol} \mathrm{eq}) \mathrm{Pd}\left(\mathrm{PPh}_{3}\right)_{4}$ was refluxed for $18 \mathrm{~h}$. The reaction mixture was filtered through a short Celite pad. Organic layer was separated and water layer extracted with EA $(2 \times 35 \mathrm{~mL})$. Collected organic layers were washed with water $\left(50 \mathrm{~mL}\right.$ ), dried over anhydrous $\mathrm{MgSO}_{4}$, filtered and concentrated in vacuum. The crude product was purified by FLC column chromatography $\left(\mathrm{SiO}_{2}\right.$, eluent: $\left.\mathrm{Cy} / \mathrm{EA}, 1 / 9\right)$ to afford $3.96 \mathrm{~g}(16.9 \mathrm{mmol}, 68 \%)$ of 34 as colourless oil. The analytical data corresponded to the literature [82].

${ }^{1} \mathbf{H}-N M R\left(300 \mathrm{MHz}, \mathrm{CDCl}_{3}\right): \delta 8.67$ (ddd, $1 \mathrm{H}, J\left(\mathrm{~B}_{5}, \mathrm{~B}_{6}\right)=5.0 \mathrm{~Hz}$ $\left.J\left(\mathrm{~B}_{4}, \mathrm{~B}_{6}\right)=1.8 \mathrm{~Hz}, J\left(\mathrm{~B}_{3}, \mathrm{~B}_{6}\right)=1.0 \mathrm{~Hz}, \mathrm{H}-\mathrm{C}_{\mathrm{B}}(6)\right), 8.18(\mathrm{dd}, 1 \mathrm{H}$, $\left.J\left(\mathrm{~A}_{2}, \mathrm{~A}_{4}\right)=J\left(\mathrm{~A}_{2}, \mathrm{~A}_{6}\right)=1.8 \mathrm{~Hz}, \mathrm{H}-\mathrm{C}_{\mathrm{A}}(2)\right), 7.88\left(\mathrm{ddd}, 1 \mathrm{H}, J\left(\mathrm{~A}_{5}, \mathrm{~A}_{6}\right)=7.9\right.$, $\left.J\left(\mathrm{~A}_{2}, \mathrm{~A}_{6}\right)=1.8 \mathrm{~Hz}, J\left(\mathrm{~A}_{4}, \mathrm{~A}_{6}\right)=1.3 \mathrm{~Hz}, \mathrm{H}-\mathrm{C}_{\mathrm{A}}(6)\right), 7.69$ (ddd, $1 \mathrm{H}$, $\left.J\left(\mathrm{~B}_{3}, \mathrm{~B}_{4}\right)=7.9 \mathrm{~Hz}, J\left(\mathrm{~B}_{4}, \mathrm{~B}_{5}\right)=7.2 \mathrm{~Hz}, J\left(\mathrm{~B}_{4}, \mathrm{~B}_{6}\right)=1.8 \mathrm{~Hz}, \mathrm{H}-\mathrm{C}_{\mathrm{B}}(4)\right), 7.63$ $\left(\mathrm{ddd}, 1 \mathrm{H}, J\left(\mathrm{~B}_{3}, \mathrm{~B}_{4}\right)=7.9 \mathrm{~Hz}, J\left(\mathrm{~B}_{3}, \mathrm{~B}_{5}\right)=1.3 \mathrm{~Hz}, J\left(\mathrm{~B}_{3}, \mathrm{~B}_{6}\right)=1.0 \mathrm{~Hz}, \mathrm{H}-\right.$ $\left.\mathrm{C}_{\mathrm{B}}(3)\right), 7.51\left(\mathrm{ddd}, 1 \mathrm{H}, J\left(\mathrm{~A}_{4}, \mathrm{~A}_{5}\right)=8.0 \mathrm{~Hz}, J\left(\mathrm{~A}_{2}, \mathrm{~A}_{4}\right)=1.8 \mathrm{~Hz}\right.$, $\left.J\left(\mathrm{~A}_{4}, \mathrm{~A}_{6}\right)=1.3 \mathrm{~Hz}, \mathrm{H}-\mathrm{C}_{\mathrm{A}}(4)\right), 7.30\left(\mathrm{dd}, 1 \mathrm{H}, J\left(\mathrm{~A}_{4}, \mathrm{~A}_{5}\right)=8.0 \mathrm{~Hz}\right.$, $\left.J\left(\mathrm{~A}_{5}, \mathrm{~A}_{6}\right)=7.9 \mathrm{~Hz}, \mathrm{H}-\mathrm{C}_{\mathrm{A}}(5)\right), 7.20\left(\mathrm{ddd}, 1 \mathrm{H}, J\left(\mathrm{~B}_{4}, \mathrm{~B}_{5}\right)=7.2 \mathrm{~Hz}\right.$, $\left.J\left(\mathrm{~B}_{5}, \mathrm{~B}_{6}\right)=5.0 \mathrm{~Hz}, J\left(\mathrm{~B}_{3}, \mathrm{~B}_{5}\right)=1.3 \mathrm{~Hz}, \mathrm{H}-\mathrm{C}_{\mathrm{B}}(5)\right)$.

${ }^{13} \mathrm{C}-\mathrm{NMR}\left(75 \mathrm{MHz}, \mathrm{CDCl}_{3}\right): \delta 155.8\left(\mathrm{~s}, \mathrm{C}_{\mathrm{B}}(2)\right), 149.8\left(\mathrm{~d}, \mathrm{C}_{\mathrm{B}}(6)\right)$, $141.4\left(\mathrm{~s}, \mathrm{C}_{\mathrm{A}}(1)\right), 136.9\left(\mathrm{~d}, \mathrm{C}_{\mathrm{B}}(4)\right), 131.9,130.0,130.3$ and $125.4(4 \times \mathrm{d}$, $\mathrm{C}_{\mathrm{A}}(2), \mathrm{C}_{\mathrm{A}}(4), \mathrm{C}_{\mathrm{A}}(5)$ and $\left.\mathrm{C}_{\mathrm{A}}(6)\right), 123.1\left(\mathrm{~s}, \mathrm{C}_{\mathrm{A}}(3)\right), 122.7\left(\mathrm{~d}, \mathrm{C}_{\mathrm{B}}(5)\right), 120.6$ $\left(\mathrm{d}, \mathrm{C}_{\mathrm{B}}(3)\right)$.

Anal. Calcd for $\mathrm{C}_{11} \mathrm{H}_{8} \mathrm{BrN}$ (234.09): C, 56.44; H, 3.44; N, 5.98 . Found: C, 56.28; H, 3.48; N, 5.62 .

\subsubsection{Synthesis of 2-(3-azidophenyl)pyridine (15)}

Compound 15 was prepared according to the general procedure C. Yield: $84 \%$. Purification: filtration through silica gel (eluent: $\mathrm{Cy} /$ EA, 1/1) Colourless liquid.

${ }^{1}$ H-NMR (300 MHz, $\mathrm{CDCl}_{3}$ ): $\delta 8.62$ (ddd, $1 \mathrm{H}, J\left(\mathrm{~B}_{5}, \mathrm{~B}_{6}\right)=4.7 \mathrm{~Hz}$, $\left.J\left(\mathrm{~B}_{4}, \mathrm{~B}_{6}\right)=1.8 \mathrm{~Hz}, J\left(\mathrm{~B}_{3}, \mathrm{~B}_{6}\right)=1.0 \mathrm{~Hz}, \mathrm{H}-\mathrm{C}_{\mathrm{B}}(6)\right), 7.71-7.60(\mathrm{~m}, 4 \mathrm{H}, \mathrm{H}-$ $\mathrm{C}_{\mathrm{A}}(2), \quad \mathrm{H}-\mathrm{C}_{\mathrm{A}}(6), \quad \mathrm{H}-\mathrm{C}_{\mathrm{B}}(3)$ and $\left.\mathrm{H}-\mathrm{C}_{\mathrm{B}}(4)\right), 7.36$ (dd, $1 \mathrm{H}$, $\left.J\left(\mathrm{~A}_{4}, \mathrm{~A}_{5}\right)=J\left(\mathrm{~A}_{5}, \mathrm{~A}_{6}\right)=7.9 \mathrm{~Hz}, \mathrm{H}-\mathrm{C}_{\mathrm{A}}(5)\right), 7.17\left(\mathrm{ddd}, 1 \mathrm{H}, J\left(\mathrm{~B}_{4}, \mathrm{~B}_{5}\right)=7.2 \mathrm{~Hz}\right.$, $\left.J\left(\mathrm{~B}_{5}, \mathrm{~B}_{6}\right)=4.7 \mathrm{~Hz}, J\left(\mathrm{~B}_{3}, \mathrm{~B}_{5}\right)=1.3 \mathrm{~Hz}, \mathrm{H}-\mathrm{C}_{\mathrm{B}}(5)\right), 6.98$ (ddd, $1 \mathrm{H}$, $\left.J\left(\mathrm{~A}_{4}, \mathrm{~A}_{5}\right)=7.9 \mathrm{~Hz}, J\left(\mathrm{~A}_{2}, \mathrm{~A}_{4}\right)=2.3 \mathrm{~Hz}, J\left(\mathrm{~A}_{4}, \mathrm{~A}_{6}\right)=1.2 \mathrm{~Hz}, \mathrm{H}-\mathrm{C}_{\mathrm{A}}(4)\right)$.

${ }^{13} \mathrm{C}-\mathrm{NMR}\left(75 \mathrm{MHz}, \mathrm{CDCl}_{3}\right): \delta 156.1\left(\mathrm{~s}, \mathrm{C}_{\mathrm{B}}(2)\right), 149.7\left(\mathrm{~d}, \mathrm{C}_{\mathrm{B}}(6)\right)$, $141.1\left(\mathrm{~s}, \mathrm{C}_{\mathrm{A}}(1)\right), 140.6\left(\mathrm{~d}, \mathrm{C}_{\mathrm{B}}(4)\right), 136.8$ and $130.0\left(2 \times \mathrm{d}, \mathrm{C}_{\mathrm{A}}(2)\right.$ and $\left.\mathrm{C}_{\mathrm{A}}(5)\right), 123.3$ and $122.6\left(2 \times \mathrm{d}, \mathrm{C}_{\mathrm{A}}(4)\right.$ and $\left.\mathrm{C}_{\mathrm{A}}(6)\right), 120.5\left(\mathrm{~s}, \mathrm{C}_{\mathrm{B}}(3)\right)$, $119.5\left(\mathrm{~d}, \mathrm{C}_{\mathrm{B}}(5)\right), 117.5\left(\mathrm{~d}, \mathrm{C}_{\mathrm{A}}(3)\right)$.

IR $v$ (solid): 3053, 2095, 1578, 1564, 1463, 1449, 1414, 1295, 1270, 1260, 991, 879, 765, 736, $666 \mathrm{~cm}^{-1}$.

Anal. Calcd for $\mathrm{C}_{11} \mathrm{H}_{8} \mathrm{~N}_{4}$ (196.21): C, 67.34; H, 4.11; N, 28.55. Found: C, 67.41; H, 4.17; N, 28.25.

\subsubsection{Synthesis of 4-azido-2-(pyridin-2-yl)phenyl acetate (16)}

Azide $675.0 \mathrm{mg}$ (3.4 mmol, $1.0 \mathrm{~mol} \mathrm{eq})$ 15, $1.22 \mathrm{~g}(3.8 \mathrm{mmol}$, $1.1 \mathrm{~mol} \mathrm{eq}) \mathrm{PhI}(\mathrm{OAc})_{2}$ and $38.6 \mathrm{mg}(0.17 \mathrm{mmol}, 0.05 \mathrm{~mol}$ eq) $\mathrm{Pd}(\mathrm{OAc})_{2}$ was suspended in a mixture of $8 \mathrm{~mL}$ benzene and $8 \mathrm{~mL}$ $\mathrm{Ac}_{2} \mathrm{O}$. The reaction vial was sealed with a Teflon cap and heated at $100{ }^{\circ} \mathrm{C}$ for $1.5 \mathrm{~h}$. Then the volatile parts were evaporated under reduced pressure, and the resulting oil purified by FLC chromatography $\left(\mathrm{SiO}_{2}\right.$, eluent: $\left.\mathrm{Cy} / \mathrm{EA}, 3 / 1\right)$. Product $446 \mathrm{mg}(1.9 \mathrm{mmol}, 57 \%)$ 16 was isolated in form of pale yellow oil.

${ }^{1} \mathbf{H}-\mathbf{N M R}\left(300 \mathrm{MHz}, \mathrm{CDCl}_{3}\right): \delta 8.70$ (ddd, $1 \mathrm{H}, J\left(\mathrm{~B}_{5}, \mathrm{~B}_{6}\right)=4.9 \mathrm{~Hz}$, $\left.J\left(\mathrm{~B}_{4}, \mathrm{~B}_{6}\right)=1.8 \mathrm{~Hz}, J\left(\mathrm{~B}_{3}, \mathrm{~B}_{6}\right)=1.0 \mathrm{~Hz}, \mathrm{H}-\mathrm{C}_{\mathrm{B}}(6)\right), 7.69$ (ddd, $1 \mathrm{H}$, $\left.J\left(\mathrm{~B}_{3}, \mathrm{~B}_{4}\right)=7.9 \mathrm{~Hz}, J\left(\mathrm{~B}_{4}, \mathrm{~B}_{5}\right)=7.8 \mathrm{~Hz}, J\left(\mathrm{~B}_{4}, \mathrm{~B}_{6}\right)=1.8 \mathrm{~Hz}, \mathrm{H}-\mathrm{C}_{\mathrm{B}}(4)\right), 7.54$ $\left(\mathrm{ddd}, 1 \mathrm{H}, J\left(\mathrm{~B}_{3}, \mathrm{~B}_{4}\right)=7.9 \mathrm{~Hz}, J\left(\mathrm{~B}_{3}, \mathrm{~B}_{5}\right)=1.1 \mathrm{~Hz}, J\left(\mathrm{~B}_{3}, \mathrm{~B}_{6}\right)=1.0 \mathrm{~Hz}, \mathrm{H}-\right.$ $\left.\mathrm{C}_{\mathrm{B}}(3)\right), 7.41\left(\mathrm{~d}, 1 \mathrm{H}, J\left(\mathrm{~A}_{2}, \mathrm{~A}_{4}\right)=2.7 \mathrm{~Hz}, \mathrm{H}-\mathrm{C}_{\mathrm{A}}(2)\right), 7.26(\mathrm{ddd}, 1 \mathrm{H}$, $\left.J\left(\mathrm{~B}_{4}, \mathrm{~B}_{5}\right)=7.8 \mathrm{~Hz}, J\left(\mathrm{~B}_{5}, \mathrm{~B}_{6}\right)=4.9 \mathrm{~Hz}, J\left(\mathrm{~B}_{3}, \mathrm{~B}_{5}\right)=1.1 \mathrm{~Hz}, \mathrm{H}-\mathrm{C}_{\mathrm{B}}(5)\right), 7.15(\mathrm{~d}$, $\left.1 \mathrm{H}, J\left(\mathrm{~A}_{4}, \mathrm{~A}_{5}\right)=8.6 \mathrm{~Hz}, \mathrm{H}-\mathrm{C}_{\mathrm{A}}(5)\right), 7.06\left(\mathrm{dd}, 1 \mathrm{H}, J\left(\mathrm{~A}_{4}, \mathrm{~A}_{5}\right)=8.6 \mathrm{~Hz}\right.$, $\left.J\left(\mathrm{~A}_{2}, \mathrm{~A}_{4}\right)=2.7 \mathrm{~Hz}, \mathrm{H}-\mathrm{C}_{\mathrm{A}}(4)\right), 2.17\left(\mathrm{~s}, 3 \mathrm{H},-\mathrm{OCOCH}_{3}\right)$.

${ }^{13} \mathrm{C}-\mathrm{NMR}\left(75 \mathrm{MHz}, \mathrm{CDCl}_{3}\right): \delta 169.3(\mathrm{~s},-\mathrm{OC}(=\mathrm{O})), 154.6\left(\mathrm{~s}, \mathrm{C}_{\mathrm{B}}(2)\right)$, $149.7\left(\mathrm{~d}, \mathrm{C}_{\mathrm{B}}(6)\right), 145.0\left(\mathrm{~s}, \mathrm{C}_{\mathrm{A}}(6)\right), 138.0\left(\mathrm{~s}, \mathrm{C}_{\mathrm{A}}(3)\right), 136.4\left(\mathrm{~d}, \mathrm{C}_{\mathrm{B}}(4)\right)$, $134.5\left(\mathrm{~s}, \mathrm{C}_{\mathrm{A}}(1)\right), 124.8$ and $123.6\left(2 \times \mathrm{d}, \mathrm{C}_{\mathrm{A}}(2)\right.$ and $\left.\mathrm{C}_{\mathrm{B}}(5)\right), 122.7,121.0$ and $120.1\left(3 \times \mathrm{d}, \mathrm{C}_{\mathrm{A}}(4), \mathrm{C}_{\mathrm{A}}(5)\right.$ and $\left.\mathrm{C}_{\mathrm{B}}(3)\right), 20.9$ (q, $\mathrm{CH}_{3} \mathrm{COO}-$ ).

IR $v$ (solid): 2958, 2928, 2107, 1724, 1595, 1486, 1463, 1287, 1269 , $1240,1128,1072,887,781,738,719,663 \mathrm{~cm}^{-1}$.

Anal. calcd for $\mathrm{C}_{13} \mathrm{H}_{10} \mathrm{~N}_{4} \mathrm{O}_{2}$ (254.24): C, 61.41; $\mathrm{H}, 3.96 ; \mathrm{N}, 22.04$. Found: C, 61.09; H, 4.07; N, 22.14.

\subsubsection{Synthesis of 4-(4-((5-(ethylsulfonyl)-2-methoxyphenyl)} (methoxycarbonyl)amino)-1H-1,2,3-triazol-1-yl)-2-(pyridin-2-yl) phenyl acetate (56a)

Compound 56a was prepared according to the general procedure D. Yield: 72\%. Purification: Flash chromatography $\left(\mathrm{SiO}_{2}\right.$, eluent: Cy/EA, 1/3). M.p. $155.0-157.5{ }^{\circ} \mathrm{C}$. Pale yellow foam.

${ }^{1}$ H-NMR (300 MHz, CDCl 3 ): $\delta 8.72$ (ddd, $1 \mathrm{H}, J\left(\mathrm{D}_{5}, \mathrm{D}_{6}\right)=4.8 \mathrm{~Hz}$, $\left.J\left(\mathrm{D}_{4}, \mathrm{D}_{6}\right)=1.8 \mathrm{~Hz}, J\left(\mathrm{D}_{3}, \mathrm{D}_{6}\right)=0.8 \mathrm{~Hz}, \mathrm{H}-\mathrm{C}_{\mathrm{D}}(6)\right), 8.46$ (br s, $1 \mathrm{H}, \mathrm{H}-$ $\left.\mathrm{C}_{\mathrm{B}}(5)\right), 8.10\left(\mathrm{~d}, 1 \mathrm{H}, J\left(\mathrm{~A}_{4}, \mathrm{~A}_{6}\right)=2.7 \mathrm{~Hz}, \mathrm{H}-\mathrm{C}_{\mathrm{A}}(6)\right), 7.92(\mathrm{dd}, 1 \mathrm{H}$, $\left.J\left(C_{5}, C_{6}\right)=8.6 \mathrm{~Hz}, J\left(C_{2}, C_{6}\right)=2.2 \mathrm{~Hz}, \mathrm{H}-\mathrm{C}_{\mathrm{C}}(6)\right), 7.88(\mathrm{~d}, 1 \mathrm{H}$, $\left.J\left(\mathrm{C}_{2}, \mathrm{C}_{6}\right)=2.2 \mathrm{~Hz}, \mathrm{H}-\mathrm{C}_{\mathrm{C}}(2)\right), 7.84\left(\mathrm{dd}, 1 \mathrm{H}, J\left(\mathrm{~A}_{3}, \mathrm{~A}_{4}\right)=8.7 \mathrm{~Hz}\right.$, $\left.J\left(\mathrm{~A}_{4}, \mathrm{~A}_{6}\right)=2.7 \mathrm{~Hz}, \mathrm{H}-\mathrm{C}_{\mathrm{A}}(4)\right), 7.77$ (ddd, $1 \mathrm{H}, J\left(\mathrm{D}_{3}, \mathrm{D}_{4}\right)=7.9 \mathrm{~Hz}$, $\left.J\left(\mathrm{D}_{4}, \mathrm{D}_{5}\right)=7.7 \mathrm{~Hz}, J\left(\mathrm{D}_{4}, \mathrm{D}_{6}\right)=1.8 \mathrm{~Hz}, \mathrm{H}-\mathrm{C}_{\mathrm{D}}(4)\right), 7.61$ (ddd, $1 \mathrm{H}$, $\left.J\left(\mathrm{D}_{3}, \mathrm{D}_{4}\right)=7.9 \mathrm{~Hz}, J\left(\mathrm{D}_{3}, \mathrm{D}_{5}\right)=1.1 \mathrm{~Hz}, J\left(\mathrm{D}_{3}, \mathrm{D}_{6}\right)=0.8 \mathrm{~Hz}, \mathrm{H}-\mathrm{C}_{\mathrm{D}}(3)\right), 7.33$ $\left(\mathrm{d}, 1 \mathrm{H}, J\left(\mathrm{C}_{5}, \mathrm{C}_{6}\right)=8.6 \mathrm{~Hz}, \mathrm{H}-\mathrm{C}_{\mathrm{C}}(5)\right), 7.29\left(\mathrm{ddd}, 1 \mathrm{H}, J\left(\mathrm{D}_{4}, \mathrm{D}_{5}\right)=7.7 \mathrm{~Hz}\right.$, $\left.J\left(\mathrm{D}_{5}, \mathrm{D}_{6}\right)=4.8 \mathrm{~Hz}, J\left(\mathrm{D}_{3}, \mathrm{D}_{5}\right)=1.1 \mathrm{~Hz}, \mathrm{H}-\mathrm{C}_{\mathrm{D}}(5)\right), 7.15(\mathrm{~d}, 1 \mathrm{H}$, $\left.J\left(\mathrm{~A}_{3}, \mathrm{~A}_{4}\right)=8.7 \mathrm{~Hz}, \mathrm{H}-\mathrm{C}_{\mathrm{A}}(3)\right), 3.88\left(\mathrm{~s}, 1 \mathrm{H}, \mathrm{C}_{\mathrm{A}}(2) \mathrm{OCH}_{3}\right), 3.77(\mathrm{~s}, 3 \mathrm{H}$, $\left.-\mathrm{NCOOCH}_{3}\right), 3.13\left(\mathrm{q}, 2 \mathrm{H}, J\left(\mathrm{CH}_{2}, \mathrm{CH}_{3}\right)=7.5 \mathrm{~Hz},-\mathrm{SO}_{2} \mathrm{CH}_{2} \mathrm{CH}_{3}\right), 2.21$ (s, $\left.3 \mathrm{H},-\mathrm{COCH}_{3}\right), 1.31\left(\mathrm{t}, 3 \mathrm{H}, \mathrm{J}\left(\mathrm{CH}_{2}, \mathrm{CH}_{3}\right)=7.5 \mathrm{~Hz},-\mathrm{SO}_{2} \mathrm{CH}_{2} \mathrm{CH}_{3}\right)$.

${ }^{13} \mathrm{C}-\mathrm{NMR}\left(75 \mathrm{MHz}, \mathrm{CDCl}_{3}\right): \delta 169.0\left(\mathrm{~s},-\mathrm{COCH}_{3}\right), 154.2$ and 153.6 $\left(2 \times \mathrm{s},-\mathrm{NCOOCH}_{3}\right.$ and $\left.\mathrm{C}_{\mathrm{D}}(2)\right), 159.8\left(\mathrm{~s}, \mathrm{C}_{\mathrm{A}}(2)\right) 149.9\left(\mathrm{~d}, \mathrm{C}_{\mathrm{D}}(6)\right), 148.0$ $\left(\mathrm{s}, \mathrm{C}_{\mathrm{C}}(4)\right), 136.6\left(\mathrm{~d}, \mathrm{C}_{\mathrm{D}}(4)\right), 135.2,134.5,131.1,2 \times 130.6,130.5(5 \times \mathrm{s}$ and $d, C_{A}(1), C_{A}(5), C_{B}(4), C_{C}(1), C_{C}(3)$ and $\left.C_{B}(5)\right), 124.9,123.7,123.0$, $2 \times 122.7,121.9$ and $121.5\left(7 \times \mathrm{d}, \mathrm{C}_{\mathrm{A}}(4), \mathrm{C}_{\mathrm{A}}(6), \mathrm{C}_{\mathrm{C}}(2), \mathrm{C}_{\mathrm{C}}(5-6), \mathrm{C}_{\mathrm{D}}(3)\right.$ and $\left.\mathrm{C}_{\mathrm{D}}(5)\right), 112.3\left(\mathrm{~d}, \mathrm{C}_{\mathrm{A}}(3)\right), 56.4\left(\mathrm{q}, \mathrm{C}_{\mathrm{A}}(2) \mathrm{OCH}_{3}\right), 53.8(\mathrm{t}$, $\left.-\mathrm{SO}_{2} \mathrm{CH}_{2} \mathrm{CH}_{3}\right), 51.1\left(\mathrm{q},-\mathrm{COOCH}_{3}\right), 21.0\left(\mathrm{q},--\overline{\mathrm{CO}} \underline{C H}_{3}\right), 7.6$ (q, $-\mathrm{SO}_{2} \mathrm{CH}_{2} \mathrm{CH}_{3}$ ).

IR $v$ (solid): 2955, 1764, 1725, 1565, 1500, 1443, 1371, 1313, 1182 , 1132, 1091, 1039, 735, $532 \mathrm{~cm}^{-1}$.

Anal. calcd for $\mathrm{C}_{26} \mathrm{H}_{25} \mathrm{~N}_{5} \mathrm{O}_{7} \mathrm{~S}$ (551.57): C, 56.62; H, 4.57; N, 12.70. Found: C, 56.72; H, 4.97; N, 12.40 .

\subsubsection{Synthesis of 4-(4-(5-(ethylsulfonyl)-2-}

methoxyphenylamino)-1H-1,2,3-triazol-1-yl)-2-(pyridin-2-yl) phenol (T3)

Compound $\mathbf{T} 3$ was prepared according to the general procedure E. Yield: $82 \%$. Purification: Flash chromatography $\left(\mathrm{SiO}_{2}\right.$, eluent: $\mathrm{Cy} /$ EA, 1/4). M.p. $148.2-149.1^{\circ} \mathrm{C}$. Pale yellow foam.

${ }^{1} \mathbf{H}-N M R\left(600 \mathrm{MHz}, \mathrm{CDCl}_{3}\right): \delta 8.56\left(\mathrm{ddd}, 1 \mathrm{H}, J\left(\mathrm{D}_{5}, \mathrm{D}_{6}\right)=5.1 \mathrm{~Hz}\right.$, $\left.J\left(\mathrm{D}_{4}, \mathrm{D}_{6}\right)=1.8 \mathrm{~Hz}, J\left(\mathrm{D}_{3}, \mathrm{D}_{6}\right)=0.9 \mathrm{~Hz}, \mathrm{H}-\mathrm{C}_{\mathrm{D}}(6)\right), 8.24(\mathrm{~d}, 1 \mathrm{H}$, $\left.J\left(\mathrm{C}_{2}, \mathrm{C}_{6}\right)=2.6 \mathrm{~Hz}, \mathrm{H}-\mathrm{C}_{\mathrm{C}}(2)\right), 8.03\left(\mathrm{ddd}, 1 \mathrm{H}, J\left(\mathrm{D}_{3}, \mathrm{D}_{4}\right)=8.3 \mathrm{~Hz}\right.$, $\left.J\left(\mathrm{D}_{3}, \mathrm{D}_{5}\right)=1.1 \mathrm{~Hz}, J\left(\mathrm{D}_{3}, \mathrm{D}_{6}\right)=0.9 \mathrm{~Hz}, \mathrm{H}-\mathrm{C}_{\mathrm{D}}(3)\right), 7.92(\mathrm{ddd}, 1 \mathrm{H}$, $\left.J\left(\mathrm{D}_{3}, \mathrm{D}_{4}\right)=8.3 \mathrm{~Hz}, J\left(\mathrm{D}_{4}, \mathrm{D}_{5}\right)=7.6 \mathrm{~Hz}, J\left(\mathrm{D}_{4}, \mathrm{D}_{6}\right)=1.8 \mathrm{~Hz}, \mathrm{H}-\mathrm{C}_{\mathrm{D}}(4)\right), 7.84$ $\left(\mathrm{s}, 1 \mathrm{H}, \mathrm{H}-\mathrm{C}_{\mathrm{B}}(5)\right), 7.64\left(\mathrm{~d}, 1 \mathrm{H}, J\left(\mathrm{~A}_{2}, \mathrm{~A}_{6}\right)=2.2 \mathrm{~Hz}, \mathrm{H}-\mathrm{C}_{\mathrm{A}}(2)\right), 7.55(\mathrm{dd}, 1 \mathrm{H}$, $\left.J\left(C_{5}, C_{6}\right)=8.8 \mathrm{~Hz}, J\left(C_{2}, C_{6}\right)=2.6 \mathrm{~Hz}, \mathrm{H}-\mathrm{C}_{\mathrm{C}}(6)\right), 7.41(\mathrm{dd}, 1 \mathrm{H}$, 
$\left.J\left(\mathrm{~A}_{3}, \mathrm{~A}_{4}\right)=8.4 \mathrm{~Hz}, J\left(\mathrm{~A}_{4}, \mathrm{~A}_{6}\right)=2.2 \mathrm{~Hz}, \mathrm{H}-\mathrm{C}_{\mathrm{A}}(4)\right), 7.34$ (ddd, $1 \mathrm{H}$, $\left.J\left(\mathrm{D}_{4}, \mathrm{D}_{5}\right)=7.6 \mathrm{~Hz}, J\left(\mathrm{D}_{5}, \mathrm{D}_{6}\right)=5.1 \mathrm{~Hz}, J\left(\mathrm{D}_{3}, \mathrm{D}_{5}\right)=1.1 \mathrm{~Hz}, \mathrm{H}-\mathrm{C}_{\mathrm{D}}(5)\right), 7.15$ $\left(\mathrm{d}, 1 \mathrm{H}, J\left(\mathrm{C}_{5}, \mathrm{C}_{6}\right)=8.8 \mathrm{~Hz}, \mathrm{H}-\mathrm{C}_{\mathrm{C}}(5)\right), 6.97\left(\mathrm{~d}, J\left(\mathrm{~A}_{3}, \mathrm{~A}_{4}\right)=8.4, \mathrm{H}-\mathrm{C}_{\mathrm{A}}(3)\right)$, $6.92($ br s, $1 \mathrm{H},-\mathrm{OH}), 4.00\left(\mathrm{~s}, 3 \mathrm{H}, \mathrm{C}_{\mathrm{A}}(2) \mathrm{OCH}_{3}\right), 3.10(\mathrm{q}, 2 \mathrm{H}$, $\left.J\left(\mathrm{CH}_{2}, \mathrm{CH}_{3}\right)=7.4 \mathrm{~Hz},-\mathrm{SO}_{2} \mathrm{CH}_{2} \mathrm{CH}_{3}\right), 1.27\left(\mathrm{t}, 3 \mathrm{H}, J\left(\mathrm{CH}_{2}, \mathrm{CH}_{3}\right)=7.4 \mathrm{~Hz}\right.$, $\left.-\mathrm{SO}_{2} \mathrm{CH}_{2} \mathrm{CH}_{3}\right)$.

${ }^{13} \mathbf{C}-\mathbf{N M R}$ ( $75 \mathrm{MHz}, \mathrm{CDCl}_{3}$, 2D-NMR: HSQC and HMBC were used for more exact carbon assignment): $\delta 160.5\left(\mathrm{~s}, \mathrm{C}_{\mathrm{C}}(4)\right), 156.5(\mathrm{~s}$, $\left.\mathrm{C}_{\mathrm{D}}(2)\right), 150.7\left(\mathrm{C}_{\mathrm{A}}(2)\right), 145.9\left(\mathrm{~d}, \mathrm{C}_{\mathrm{D}}(6)\right), 138.3\left(\mathrm{~s}, \mathrm{C}_{\mathrm{B}}(4)\right), 133.4$ and $130.6\left(2 \times s, C_{A}(1)\right.$ and $\left.C_{A}(5)\right), 128.9\left(s, C_{C}(3)\right), 2 \times 123.7(s$ and $d$, $\mathrm{C}_{\mathrm{C}}(1)$ and $\left.\mathrm{C}_{\mathrm{C}}(6)\right), 122.5\left(\mathrm{~d}, \mathrm{C}_{\mathrm{D}}(5)\right), 120.4\left(\mathrm{~d}, \mathrm{C}_{\mathrm{A}}(4)\right), 119.6$ and 119.5 $\left(2 \times d, C_{C}(5)\right.$ and $\left.C_{D}(3)\right), 119.3\left(d, C_{D}(4)\right), 119.0\left(d, C_{C}(2)\right), 111.0(d$, $\left.\mathrm{C}_{\mathrm{A}}(6)\right), 109.6$ and $109.5\left(2 \times \mathrm{d}, \mathrm{C}_{\mathrm{A}}(3)\right.$ and $\left.\mathrm{C}_{\mathrm{B}}(5)\right), 56.2\left(\mathrm{q}, \mathrm{C}_{\mathrm{A}}(2) \mathrm{OCH}_{3}\right)$, $50.8\left(\mathrm{t},-\mathrm{SO}_{2} \mathrm{CH}_{2} \mathrm{CH}_{3}\right), 7.6\left(\mathrm{q},-\mathrm{SO}_{2} \mathrm{CH}_{2} \mathrm{CH}_{3}\right)$.

IR $v$ (solid): 3354, 2939, 1597, 1566, 1509, 1428, 1302, 1260, 1142, 1123, 792, $735 \mathrm{~cm}^{-1}$.

Anal. calcd for $\mathrm{C}_{22} \mathrm{H}_{21} \mathrm{~N}_{5} \mathrm{O}_{4} \mathrm{~S}$ (451.50): C, 58.52; H, 4.69; N, 15.51. Found: C, 58.62; H, 4.62; N, 15.40.

\subsection{In vitro VGEFR-2 kinase assay}

A radiometric protein kinase assay $\left({ }^{33}\right.$ PanQinase ${ }^{\circledR}$ Activity Assay) was used for measuring the activity of VEGFR2 protein kinase. VEGFR2 tyrosine kinase was expressed in Sf9 insect cells as human recombinant GST-fusion protein. The kinase was purified by affinity chromatography using GSH-agarose. The purity of the kinase was checked by SDS-PAGE/silver staining and the identity of the kinase was verified by mass spectroscopy. $\mathrm{IC}_{50}$ values were measured by testing 10 concentrations from $1 \mathrm{E}-4$ to $1 \mathrm{E}-9 \mathrm{M}$ of each compound at $1 \mu \mathrm{M}$ ATP conc. The measurements were performed by ProQinase GmbH, Freiburg, Germany [25].

\subsection{In vitro cytotoxic tumour cell lines evaluation}

\subsubsection{Cell culture}

Huh7 and Mahlavu [80], human Hepatocellular Carcinoma (HCC) cells (ATCC) were maintained in Dulbecco's Modified Eagle's Medium (DMEM) (Invitrogen GIBCO), with 10\% fetal bovine serum (FBS) (Invitrogen GIBCO), 2 mM L-glutamine, $0.1 \mathrm{mM}$ nonessential amino acids, 100 units/mL penicillin and $100 \mathrm{~g} / \mathrm{mL}$ streptomycin at $37{ }^{\circ} \mathrm{C}$ in a humidified incubator under $5 \% \mathrm{CO}_{2}$. Both Huh7 and Mahlavu cells are tested their authentication by STR analysis.

\subsubsection{NCI-60 Sulforhodamine B (SRB) cytotoxicity assay}

SRB is anionic dye that can bind to proteins. The SRB assay measures the cellular protein content in order to determine cell density since cell proliferation is directly proportional to total protein synthesis [81].

Method: Huh7 (2000 cell/well) and Mahlavu (1000 cell/well) cells were inoculated into 96 well plates ( $150 \mu \mathrm{l} /$ well). $24 \mathrm{~h}$ later, molecules of interest and DMSO control were applied in concentrations $40 \mu \mathrm{M}-2.5 \mu \mathrm{M}$ in serial dilutions. After $72 \mathrm{~h}$ of treatment, cells were fixed by cold $10 \%(\mathrm{w} / \mathrm{v}$ ) trichloroacetic acid (MERCK) for an hour. Then the wells were washed with $\mathrm{ddH}_{2} \mathrm{O}$ and dried. $50 \mu \mathrm{l}$ of $0.4 \%$ SRB dye (Sigma-Aldrich) was applied to each well and incubated at RT for $10 \mathrm{~min}$. Then wells were washed with $1 \%$ acetic acid and left for air-drying. SRB dye was solubilized in a $100 \mu \mathrm{l}$ $10 \mathrm{mM}$ Tris-Base solution and the absorbance was measured at $515 \mathrm{~nm}$. The experiment was performed in triplicates and the absorbance values were normalized to DMSO controls. Standard deviations were less than $10 \%$.

\section{Acknowledgements}

This work was supported by program Cotutelle a joined supervision of Margaréta Vojtičková doctoral thesis between University of Strasbourg France (supervised by Gilles Hanquet) and Comenius University in Bratislava, Slovakia (supervised by Andrej Boháč). The research was supported by Biomagi, Ltd., VEGA grant 1/ 0634/13, University of Strasbourg, ITMS 26240220086 and TUBITAK-COST grant \#113S540. For implementation the concept of Spider-like (CRAAC) molecule we thank to Biomagi, Ltd. Slovakia. The COST action CM0602 (AngioKem), CM1106 (StemChem) and Nadine Martinet (nadine.martinet@inserm.fr) compound library for research groups networking (G. Hanquet, A. Boháč, Rengul Cetin-Atalay) and STSM tool is also acknowledged. For druglikeness predictions we thank the Molinspiration Property Calculation Service. This paper is dedicated to memory of prof. Jozef Boháč.

\section{Appendix A. Supplementary data}

Supplementary data associated with this article can be found in the online version, at http://dx.doi.org/10.1016/j.ejmech.2015.08. 012. These data include physico-chemical characteristics, spectra and spectra graphical abstracts of prepared compounds depicted in Scheme 12 (also those not included in this printed version), MOL files and InChiKeys of the most important compounds described in this article.

\section{References}

[1] W. Risau, Mechanisms of angiogenesis, Nature 386 (1997) 671-674. http://dx. doi.org/10.1038/386671a0.

[2] T. Boehm, J. Folkman, T. Browder, Antiangiogenic therapy of experimental cancer does not induce acquired drug resistance, Nature 390 (1997) 404-407. http://dx.doi.org/10.1038/37126.

[3] A.K. Olsson, A. Dimberg, J. Kreuger, L. Claesson-Welsh, VEGF receptor signalling - in control of vascular function, Nat. Rev. Mol. Cell Biol. 7 (2006) 359-371, http://dx.doi.org/10.1038/nrm1911.

[4] P. Carmeliet, VEGF as a key mediator of angiogenesis in cancer, Oncology 69 (2005) 4-10. http://dx.doi.org/10.1159/000088478.

[5] N. Ferrara, K.J. Hillan, H.P. Gerber, W. Novotny, Discovery and development of bevacizumab, an anti-VEGF antibody for treating cancer, Nat. Rev. Drug Disc. 3 (2004) 391-400. http://dx.doi.org/10.1038/nrd1381.

[6] S.L. Fine, D.F. Martin, P. Kirkpatrick, Pegaptanib sodium, Nat. Rev. Drug Disc 4 (2005) 187-188. http://dx.doi.org/10.1038/nrd1677.

[7] M. Shibata, M.M. Shen, The roots of cancer: stem cells and the basis for tumor heterogeneity, Bio Essays 35 (2013) 253-260. http://dx.doi.org/10.1002/bies. 201200101.

[8] S.D. Finley, A.S. Popel, Predicting the effects of anti-angiogenic agents targeting specific VEGF isoforms, AAPS J. 14 (2012) 500-509. http://dx.doi.org/ 10.1208/s12248-012-9363-4.

[9] P. Hamerlik, J.D. Lathia, R. Rasmussen, Q. Wu, J. Bartkova, M. Lee, P. Moudry, J. Bartek Jr., W. Fischer, J. Lukas, J.N. Rich, J. Bartek, Autocrine VEGF-VEGFR2-Neuropilin-1 signaling promotes glioma stem-like cell viability and tumor growth, J. Exp. Med. 209 (2012) 507-520. http://dx.doi. org/10.1084/jem.20111424.

[10] C. Xu, X. Wu, J. Zhu, VEGF promotes proliferation of human glioblastoma multiforme stem-like cells through VEGF receptor 2, Sci. World J. (2013) 8. ID 417413, http://dx.doi.org/10.1155/2013/417413.

[11] X. Yao, Y. Ping, Y. Liu, K. Chen, T. Yoshimura, M. Liu, W. Gong, C. Chen, Q. Niu, D. Guo, X. Zang, J.M. Wang, X. Bian, Vascular endothelial growth factor receptor 2 (VEGFR-2) plays a key role in vasculogenic mimicry formation, neovascularization and tumor initiation by glioma stem-like cells, PLoS One 8 (2013) e57188. http://dx.doi.org/10.1371/journal.pone.0057188.

[12] P.A. Harris, M. Cheung, R.N. Hunter, M.L. Brown, J.M. Veal, R.T. Nolte, L. Wang, W. Liu, R.M. Crosby, J.H. Johnson, A.H. Epperly, R. Kumar, D.K. Luttrell, J.A. Stafford, Discovery and evaluation of 2-Anilino-5-aryloxazoles as a novel class of VEGFR2 kinase inhibitors, J. Med. Chem. 48 (2005) 1610-1619. http:// dx.doi.org/10.1021/jm049538w.

[13] L. Lintnerová, L. Kováčiková, G. Hanquet, A. Boháč, Selected methodologies convenient for the synthesis of N,5-Diaryloxazole-2-amine pharmacophore, J. Heterocyc. Chem. 52 (2015) 425-439. http://dx.doi.org/10.1002/jhet.2063.

[14] L. Lintnerová, M. García-Caballero, F. Gregáň, M. Melicherčík, A.R. Quesada J. Dobiaš, J. Lác, M. Sališová, A. Boháć, A development of chimeric VEGFR2 TK inhibitor based on two ligand conformers from PDB: 1Y6A complex - medicinal chemistry consequences of a TKs analysis, Eur. J. Med. Chem. 72 (2014) 146-159. http://dx.doi.org/10.1016/j.ejmech.2013.11.023.

[15] N. Bimal, B.S. Sekhon, An overview of isosteric/bioisosteric/scaffold hopping modification in drug design, Inven. Impact Med. Chem. 4 (2012) 178-190. 
Article ID- “ Inventi:pmc/210/12”, 2012, Available From: http://inventi.in/ journal/article/impact/5/4123/med-chem/pi (visited 19.02.2015).

[16] V. Rostovtsev, L.G. Green, V.V. Fokin, K.B. Sharpless, A stepwise huisgen cycloaddition process: copper(I)-catalyzed regioselective "Ligation" of azides and terminal alkynes, Angew. Chem. Int. Ed. 41 (2002) 2596-2599. <2596: AID-ANIE2596>3.0.CO;2-4, http://dx.doi.org/10.1002/1521-3773(20020715) 41:14.

[17] L. Zhang, X. Chen, P. Xue, H.H.Y. Sun, I.D. Williams, K.B. Sharpless, V.V. Fokin, G. Jia, Ruthenium-catalyzed cycloaddition of alkynes and organic azides, J. Am. Chem. Soc. 127 (2005) 15998-15999. http://dx.doi.org/10.1021/ja054114s.

[18] Database REAXYS https://www.reaxys.com/(last accessed 08.06.14).

[19] N. Miyamoto, N. Sakai, T. Hirayama, K. Miwa, Y. Oguro, H. Oki, K. Okada T. Takagi, H. Iwata, Y. Awazu, S. Yamasaki, T. Takeuchi, H. Miki, A. Hori, S. Imamura, Discovery of N-[5-(\{2-[(cyclopropylcarbonyl)amino]imidazo[1,2b]pyridazin-6-yl\}oxy)-2-methylphenyl]-1,3-dimethyl-1H-pyrazole-5carboxamide (TAK-593), a highly potent VEGFR2 kinase inhibitor, Bioorg. Med. Chem. 21 (2013) 2333-2345. http://dx.doi.org/10.1016/j.bmc.2013.01. 074.

[20] S. Hata, Y. Yuki, S.W. Claridge, S. Raeppel, A. Vaisburg, Inhibitors of Protein Tyrosine Kinase Activity, U. S. Patent: US2013/96136 A1, 2013.

[21] L.F. Hennequin, A.P. Thomas, C. Johnstone, E.S.E. Stokes, P.A. Ple, J.J. Lohmann, D.J. Ogilvie, M. Dukes, S.R. Wedge, J.O. Curwen, J. Kendrew, C.L. van der Brempt, Design and structure-activity relationship of a new class of poten VEGF receptor tyrosine kinase inhibitors, J. Med. Chem. 42 (1999) 5369-5389. http://dx.doi.org/10.1021/jm990345w.

[22] L.F. Hennequin, E.S.E. Stokes, A.P. Thomas, C. Johnstone, P.A. Ple, D.J. Ogilvie, M. Dukes, S.R. Wedge, J. Kendrew, J.O. Curwen, Novel 4-anilinoquinazolines with C-7 basic side chains: design and structure activity relationship of a series of potent, orally active, VEGF receptor tyrosine kinase inhibitors, J. Med. Chem. 45 (2002) 1300-1312. http://dx.doi.org/10.1021/jm011022e.

[23] M.R. Michaelides, J.H. Holms, D.H. Steinman, Abbott Laboratories, Indazole Inhibitors of Kinase, U. S. Patent: US2011/281868 A1, 2011.

[24] A. Jonczyk, W. Rautenberg, N-oxides of Heterocyclic Substituted Bisarylureas for Treating Kinase-mediated Diseases, Merck patent: WO2007/115670 A1, 2007.

[25] Determination of inhibition IC $_{50}$ activity on VEGFR2 receptor has been performed by ProQinase GmbH, Freiburg, Germany http://www.proqinase.com/ (last accessed 08.06.14)

[26] PDB (Protein Data Bank) http://www.rcsb.org/pdb/home/home.do (last accessed 08.06.14)

[27] I. Akritopoulou-Zanze, B.D. Wakefield, A. Gasiecki, D. Kalvin, E.F. Johnson, P. Kovar, S.W. Djuric, Scaffold oriented synthesis. Part 3: design, synthesis and biological evaluation of novel 5-substituted indazoles as potent and selective kinase inhibitors employing [2+3] cycloadditions, Bioorg. Med. Chem. Lett. 21 (2011) 1476-1479. http://dx.doi.org/10.1016/j.bmcl.2011.01.007.

[28] G. Gu, H. Wang, P. Liu, C. Fu, Z. Li, X. Cao, Y. Li, Q. Fang, F. Xu, J. Shen, P.G. Wang, Discovery and structural insight of a highly selective protein kinase inhibitor hit through click chemistry, Chem. Commun. 48 (2012) 2788-2790. http://dx.doi.org/10.1039/C1CC15851A.

[29] A.S. Kiselyov, M. Semenova, V.V. Semenov, (1,2,3-Triazol-4-yl)benzenamines: synthesis and activity against VEGF receptors 1 and 2, Bioorg. Med. Chem. Lett. 19 (2009) 1344-1348. http://dx.doi.org/10.1016/j.bmcl.2009.01.046.

[30] C. Beier, M. Zacharias, Tackling the challenges posed by target flexibility in drug design, Expert Opin. Drug Discov. 5 (2010) 347-359. http://dx.doi.org 10.1517/17460441003713462.

[31] O. Rabal, G. Schneider, J.I. Borrell, J. Teixido, Structure-based Virtual screening of FGFR inhibitors, BioDrugs 21 (2007) 31-45. http://dx.doi.org/10.2165/ 00063030-200721010-00005

[32] C.N. Cavasotto, R.A. Abagyan, Protein flexibility in ligand docking and virtual screening to protein kinases, J. Mol. Biol. 337 (2004) 209-225. http://dx.doi. $\operatorname{org} / 10.1016 /$ j.jmb.2004.01.003.

[33] http://dock.compbio.ucsf.edu/DOCK3.6/(last accessed 08.06.14)

[34] C.A. Lipinski, F. Lombardo, B.W. Dominy, P.J. Feeney, Experimental and computational approaches to estimate solubility and permeability in drug discovery and development settings, Adv. Drug. Deliv. Rev. 23 (1997) 3-25. http://dx.doi.org/10.1016/S0169-409X(96)00423-1.

[35] P. Ertl, B. Rohde, P.J. Selzer, Fast calculation of molecular polar surface area as a sum of fragment-based, contributions and its application to the prediction of drug transport properties, J. Med. Chem. 43 (2000) 3714-3717. http://dx.doi. org/10.1021/jm000942e.

[36] H.J. Verheij, Leadlikeness and structural diversity of synthetic screening libraries, Mol. Diver 10 (2006) 377-388. http://dx.doi.org/10.1007/s11030006-9040-6.

[37] D.F. Veber, S.R. Johnson, H.Y. Cheng, B.R. Smith, K.W. Ward, K.D. Kopple, Molecular properties that influence the oral bioavailability of drug candidates, J. Med. Chem. 45 (2002) 2615-2623. http://dx.doi.org/10.1021/jm020017n.

[38] Molinspiration Property Calculation Service http://www.molinspiration.com/ cgi-bin/properties (last accessed 08.06.14)

[39] a) J. Bode, Ueber einige Abkömmlinge des Neurins und Cholins, Liebigs Ann. Chem. 267 (1892) 268-299. http://dx.doi.org/10.1002/jlac.18922670208; b) F. Klages, E. Drerup, Über 1-Amino-vinyläther, Liebigs Ann. Chem. 547 (1941) 65-72. http://dx.doi.org/10.1002/jlac.19415470104;

c) For the first practical synthesis see: H.G. Viehe, Synthesis of substituted acetylenic compounds Angew. Chem. Int. Ed. 2 (1963) 477 (and), http://dx.doi. org/10.1002/anie.196304771; d) H.G. Viehe, Synthesis and reactions of the alkynylamines, Angew. Chem. Int. Ed. 6 (1967) 767-778. http://dx.doi.org/10.1002/anie.196707671.

[40] a) J.A. Mulder, K.C.M. Kurtz, R.P. Hsung, In search of an atom-economical synthesis of Chiral ynamides, Synlett (2003) 1379-1390. http://dx.doi.org/ 10.1055/s-2003-40817;

b) K.A. DeKorver, H. Li, A.G. Lohse, R. Hayashi, Z. Lu, Y. Zhang, R.P. Hsung, Ynamides: a modern functional group for the new millennium, Chem. Rev. 110 (2010) 5064-5106. http://dx.doi.org/10.1021/cr100003s.

[41] Z. Janousek, J. Collard, H.G. Viehe, Reaction of secondary acetamides with Ndichloromethylene-N,N-dimethylammonium chloride, Angew. Chem. Int. Ed. 11 (1972) 917-918. http://dx.doi.org/10.1002/anie.197209171.

[42] M. Murár, G. Addová, A. Boháč, Synthesis of 5-(ethylsulfonyl)-2methoxyaniline: an important pharmacological fragment of VEGFR2 and other inhibitors, Beilstein J. Org. Chem. 9 (2013) 173-179. http://dx.doi.org/ 10.3762/bjoc.9.20.

[43] a) E.J. Corey, P.L. Fuchs, A synthetic method for formyl $\rightarrow$ ethynyl conversion $\left(\mathrm{RCHO} \rightarrow \mathrm{RC} \equiv \mathrm{CH}\right.$ or $\mathrm{RC} \equiv \mathrm{CR}^{\prime}$ ), Tetrahedron Lett. 13 (1972) 3769-3772. http:// dx.doi.org/10.1016/S0040-4039(01)94157-7b);

b) D. Brückner, Synthesis of ynamides from formamides, Tetrahedron 62 (2006) 3809-3814. http://dx.doi.org/10.1016/j.tet.2005.11.091;

c) D. Brückner, Synthesis of ynamides and Ynol ethers via formamides and formates, Synlett (2000) 1402-1404. http://dx.doi.org/10.1055/s-2000-7629.

[44] a) S. Ohira, Methanolysis of dimethyl (1-diazo-2-oxopropyl) phosphonate: generation of dimethyl (diazomethyl) phosphonate and reaction with carbonyl compounds, Syn. Comm. 19 (1989) 561-564. http://dx.doi.org/10. 1080/00397918908050700;

b) G.J. Roth, B. Liepold, S.G. Müller, H.J. Bestmann, Further improvements of the synthesis of alkynes from aldehydes, Synthesis 1 (2004) 59-62. http://dx. doi.org/10.1055/s-2003-44346.

[45] a) A.J. Speziale, L.R. Smith, Reaction of phosphorus compounds. IV. Haloenamines and imidoyl chlorides from reaction of phosphines with haloamides, J. Am. Chem. Soc. 84 (1962) 1868-1876. http://dx.doi.org/10.1021/ ja00869a021;

b) G. Himbert, M. Regitz, Untersuchungen an Diazoverbindungen und Aziden, XIV. Guanyldiazomethane durch Diazogruppen-Übertragung auf $\beta \mathrm{H}$-Inamine, Chem. Berichte 105 (1972) 2963-2974. http://dx.doi.org/10.1002/cber. 19721050919.

[46] a) B. Witulski, T. Stengel, N-Functionalized 1-Alkynylamides: new building blocks for transition metal mediated inter- and intramolecular $[2+2+1]$ cycloadditions, Angew. Chem. Int. Ed. 37 (1998) 489-492. <489::AIDANIE489>3.0.CO;2-N, http://dx.doi.org/10.1002/(SICI)1521-3773(19980302) $37: 4$

b) B. Witulski, M. Gößmann, Intermolecular Pauson-Khand reactions with Nalkynylamides - electronically tuned variants of ynamines, Synlett (2000) 1793-1797. http://dx.doi.org/10.1055/s-2000-8685;

c) B. Witulski, T. Stengel, Rhodium(I)-catalyzed $[2+2+2]$ cycloadditions with n-functionalized 1-alkynylamides: a conceptually new strategy for the regiospecific synthesis of substituted Indolines, Angew. Chem. Int. Ed. 38 (1999) 2426-2430. <2426::AID-ANIE2426>3.0.CO;2-Y, http://dx.doi.org/10. 1002/(SICI)1521-3773(19990816)38:16;

d) B. Witulski, T. Stengel, J.M. Fernandez-Hernandez, Chemo- and regioselective crossed alkynecyclotrimerisation of 1,6-diynes with terminal monoalkynes mediated by Grubbs' catalyst or Wilkinson's catalyst, Chem. Commun. (2000) 1965-1966. http://dx.doi.org/10.1039/B005636G;

e) B. Witulski, C. Alayrac, A highly efficient and flexible synthesis of substituted carbazoles by rhodium-catalyzed inter- and intramolecular alkyne cyclotrimerizations, Angew. Chem. Int. Ed. 41 (2002) 3281-3284. <3281:: AID-ANIE3281>3.0.CO;2-G, http://dx.doi.org/10.1002/1521-3773(20020902) 41:17.

[47] a) J.D. Rainier, J.E. Imbriglio, The synthesis and chemoselective reactivity of 3aminocyclopentadienones, J. Org. Chem. 65 (2000) 7272-7276. http://dx.doi. org/10.1021/jo001044t;

b) J.D. Rainier, J.E. Imbriglio, Synthesis and chemoselective reactivity of 3aminocyclopentadienones, Org. Lett. 1 (1999) 2037-2039. http://dx.doi.org/ $10.1021 / 019912128$

[48] a) P. Murch, B.L. Williamson, P.J. Stang, Push-pull ynamines via alkynyliodonium chemistry, Synthesis 12 (1994) 1255-1256. http://dx.doi.org/10.1055/s1994-25675;

b) V.V. Zhdankin, P.J. Stang, Alkynyliodonium salts in organic synthesis, Tetrahedron 54 (1998) 10927-10966. http://dx.doi.org/10.1016/S0040-4020(98) 00410-4.

[49] a) T. Kitamura, N. Tashi, K. Tsuda, Y. Fujiwara, Alkynylbenzotriazoles by direct alkynylation of benzotriazole using alkynyliodonium salts, Tetrahedron Lett. 39 (1998) 3787-3790. http://dx.doi.org/10.1016/S0040-4039(98)00617-0; b) T. Kitamura, N. Tashi, K. Tsuda, H. Chen, Y. Fujiwara, A convenient synthesis of new 1-alkynyl-1H-benzotriazoles by reaction of alkynyl(phenyl)iodonium salts with benzotriazole ion, Heterocycles 52 (2000) 303-312. http://dx.doi. org/10.3987/COM-99-S25.

[50] A. Klapars, X. Huang, S.L. Buchwald, A general and efficient copper catalyst for the amidation of aryl halides, J. Am. Chem. Soc. 124 (2002) 7421-7428. http:// dx.doi.org/10.1021/ja0260465.

[51] Y. Zhang, R.P. Hsung, M.R. Tracey, K.C.M. Kurtz, E.L. Vera, Copper sulfatepentahydrate-1,10-phenanthroline catalyzed amidations of alkynyl bromides. Synthesis of heteroaromatic amine substituted ynamides, Org. Lett. 6 (2004) 1151-1154. http://dx.doi.org/10.1021/ol049827e. 
[52] K. Villeneuve, N. Riddell, W. Tam, Ruthenium-catalyzed [2+2] cycloadditions of bicyclic alkenes and ynamides, Tetrahedron 62 (2006) 3823-3836. http:// dx.doi.org/10.1016/j.tet.2005.11.081.

[53] T. Skrydstrup, K. Dooleweerdt, H. Birkedal, T. Ruhland, Irregularities in the effect of potassium phosphate in ynamide synthesis, J. Org. Chem. 73 (2008) 9447-9450. http://dx.doi.org/10.1021/jo801935b.

[54] R. Trokowski, S. Akine, T. Nabeshima, Selective binding of benzenediol derivatives by simultaneous non-covalent interactions in bis-Pt(II) aza-aromatic host-guest system, Dalton Trans. 46 (2009) 10359-10366. http://dx.doi.org/ 10.1039/B911602H.

[55] J. Andersen, U. Madsen, F. Björkling, X. Liang, Rapid synthesis of aryl azides from aryl halides under mild conditions, Synlett (2005) 2209-2213. http://dx. doi.org/10.1055/s-2005-872248.

[56] L.V. Desai, H.A. Malik, M.S. Sanford, Oxone as an inexpensive, safe, and environmentally benign oxidant for $\mathrm{C}-\mathrm{H}$ bond oxygenation, Org. Lett. 8 (2006) 1141-1144. http://dx.doi.org/10.1021/ol0530272.

[57] W. Li, D.P. Nelson, M.S. Jensen, R.S. Hoerrner, D. Cai, R.D. Larsen, Synthesis of 3-pyridylboronic acid and its pinacol ester. Application of 3-pyridylboronic acid in Suzuki coupling to prepare 3-pyridin-3-ylquinoline, Org. Synth. 81 (2005) 89-97. http://dx.doi.org/10.15227/orgsyn.081.0089.

[58] A.T. Shinde, S.B. Zangade, S.B. Chavan, A.Y. Vibhute, Y.S. Nalwar, Y.B. Vibhute, A practical iodination of aromatic compounds by using iodine and iodic acid, Synth. Commun. 40 (2010) 3506-3513. http://dx.doi.org/10.1080/ 00397910903457332.

[59] S. Kotha, V.R. Shah, Design and synthesis of 1-benzazepine derivatives by strategic utilization of Suzuki-Miyaura cross-coupling, aza-Claisen rearrangement and ring-closing metathesis, Eur. J. Org. Chem. (2008) 1054-1064. http://dx.doi.org/10.1002/ejoc.200700921.

[60] T. Ganesh, P. Thepchatri, L.L.Y. Du, H. Fu, J.P. Snyder, A. Sun, Synthesis and SAR study of N-(4-hydroxy-3-(2-hydroxynaphthalene-1-yl)phenyl)-arylsulfonamides: heat shock protein 90 (Hsp90) inhibitors with submicromolar activity in an in vitro assay, Bio. Med. Chem. Lett. 18 (2008) 4982-4987. http://dx.doi. org/10.1016/j.bmcl.2008.08.022.

[61] S. Chandrappa, T. Vinaya, T. Ramakrishnappa, K.S. Rangappa, An efficient method for aryl nitro reduction and cleavage of azo compounds using iron powder/calcium chloride, Synlett (2010) 3019-3022. http://dx.doi.org/10. 1055/s-0030-1259067.

[62] R. Walton, P.M. Lahti, An Efficient, Simple synthesis of 4-azidobenzaldehyde, Synth. Commun. 28 (1998) 1087-1092. http://dx.doi.org/10.1080/ 00397919808003077.

[63] Q.H. Deng, J.C. Wang, Z.J. Xu, C.Y. Zhou, C.M. Che, Metal-free intramolecular aziridination of allylic carbamates mediated by hypervalent iodine compounds, Synthesis 18 (2011) 2959-2967. http://dx.doi.org/10.1055/s-00301260150.

[64] R.A. Altman, S.L. Buchwald, Pd-catalyzed Suzuki-Miyaura reactions of aryl halides using bulky biarylmonophosphine ligands, Nat. Protoc. 2 (2007) 3115-3121. http://dx.doi.org/10.1038/nprot.2007.411.

[65] Z. Gu, A. Zakarian, Total synthesis of rhazinilam: axial to point Chirality transfer in an enantiospecific Pd-catalyzed transannular cyclization, Org. Lett. 12 (2010) 4224-4227. http://dx.doi.org/10.1021/ol101523z.

[66] M.D. Morrison, J.J. Hanthorn, D.A. Pratt, Synthesis of pyrrolnitrin and related halogenated phenylpyrroles, Org. Lett. 11 (2009) 1051-1054. http://dx.doi. org/10.1021/ol8026957.

[67] L.C.W. Chang, A.P. Ijzerman, J. Brussee, Antagonists to treat neurodegenerative diseases like Parkinson's disease; 2,4,6-trisubstituted pyrimidines; N-(2,6diphenyl-pyrimidin-4-yl)-benzamide, US Patent: US 2007/0032510 2004. https://www.google.co.in/patents/US20070032510?

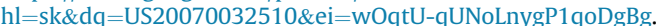

[68] C. Ye, H. Gao, D.G.W. Boatz, B. Twamley, J.M. Shreeve, Polyazidopyrimidines: high-energy compounds and precursors to carbon nanotubes, Angew. Chem. Int. Ed. 45 (2006) 7262-7265. http://dx.doi.org/10.1002/anie.200602778.

[69] H.C. Kolb, M.G. Finn, K.B. Sharpless, Click chemistry: diverse chemical function from a few good reactions, Angew. Chem. Int. Ed. 40 (2001) 2004-2021. $<2004:$ :AID-ANIE2004>3.0.CO;2-5, http://dx.doi.org/10.1002/15213773(20010601)40:11.

[70] C.R. Becer, R. Hoogenboom, U.S. Schubert, Click chemistry beyond metalcatalyzed cycloaddition, Angew. Chem. Int. Ed. 48 (2009) 4900-4908. http://dx.doi.org/10.1002/anie.200900755.

[71] C.M. Coleman, D.F. O'Shea, New organolithium addition methodology to diversely functionalized Indoles, J. Am. Chem. Soc. 125 (2003) 4054-4055 http://dx.doi.org/10.1021/ja034283h.

[72] E.A. Englund, H.N. Gopi, D.H. Appella, An efficient synthesis of a probe for protein function: 2,3-Diaminopropionic acid with orthogonal protecting groups, Org. Lett. 6 (2004) 213-215. http://dx.doi.org/10.1021/ol0361599.

[73] F. Mongin, A.-S. Rebstock, F. Trécourt, G. Quéguiner, F. Marsais, Synthesis and deprotonation of 2-(Halophenyl)pyridines and 1-(Halophenyl)isoquinolines, J. Org. Chem. 69 (2004) 6766-6771. http://dx.doi.org/10.1021/jo049454v.

74] I. Sapountzis, H. Dube, R. Lewis, N. Gommermann, P. Knochel, Synthesis of functionalized nitroarylmagnesium halides via an Iodine-Magnesium exchange, J. Org. Chem. 70 (2005) 2445-2454. http://dx.doi.org/10.1021/ jo0481320.

[75] F.D. Bellamy, K. Ou, Selective reduction of aromatic nitro compounds with stannous chloride in non acidic and non aqueous medium, Tetrahedron Lett. 25 (1984) 839-842. http://dx.doi.org/10.1016/S0040-4039(01)80041-1.

[76] http://wiki.bkslab.org/index.php/DOCK 3.6 (last accessed 08.06.14).

[77] M. Remko, A. Boháč, L. Kováčiková, Molecular structure, pKa, lipophilicity, solubility, absorption, polar surface area, and blood brain barrier penetration of some antiangiogenic agents, Struct. Chem. 22 (2011) 635-648. http://dx. doi.org/10.1007/s11224-011-9741-z.

[78] Discovery Studio http://accelrys.com/products/discovery-studio/ visualization-download.php (last accessed 08.06.14).

[79] J.J. Irwin, B.K. Shoichet, M.M. Mysinger, N. Huang, F. Colizzi, P. Wassam, Y. Cao, Automated docking screens: a feasibility study, J. Med. Chem. 52 (2009) 5712-5720. http://dx.doi.org/10.1021/jm9006966.

[80] F. Buontempo, T. Ersahin, S. Missiroli, S. Senturk, D. Etro, M. Ozturk S. Capitani, R. Cetin-Atalay, M.L. Neri, Inhibition of Akt signaling in hepatoma cells induces apoptotic cell death independent of Akt activation status, Investig. New Drugs 29 (2011) 1303-1313, http://dx.doi.org/10.1007/s10637 010-9486-3.

[81] V. Vichai, K. Kirtikara, Sulforhodamine B colorimetric assay for cytotoxicity screening, Nat. Protoc. 1 (2006) 1112-1116, http://dx.doi.org/10.1038/ nprot.2006.179.

[82] S. Kotha, V.R. Shah, Design and synthesis of 1-Benzazepine derivatives by strategic Utilization of Suzuki-Miyaura cross-coupling, aza-Claisen rearrangement and ring-Closing metathesis, Eur. J. Org. Chem. (2008) 1054-1064 (synthesis of 45 see Supplementary Material), http://dx.doi.org/10.1002/ejoc. 200700921.

\section{Further reading}

[1] K. Billingsley, S.L. Buchwald, Highly efficient monophosphine-based catalyst for the palladium-catalyzed Suzuki-Miyaura reaction of heteroaryl halides and heteroaryl boronic acids and esters, J. Am. Chem. Soc. 129 (2007) 3358-3366 (synthesis of 54 see Supplementary Material), http://dx.doi.org/10.1021/ ja068577p.

[2] I. Sapountzis, H. Dube, R. Lewis, N. Gommermann, P. Knochel, Synthesis of functionalized nitroarylmagnesium halides via an Iodine-Magnesium exchange, J. Org. Chem. 70 (2005) 2445-2454 (synthesis of 67 see Supplementary Material), http://dx.doi.org/10.1021/jo048132o.

[3] A.K. Atta, S.-B. Kim, D.-G. Cho, $\mathrm{Hg}$ (II)-Mediated intramolecular cyclization reaction in aqueous Media and its application as $\mathrm{Hg}(\mathrm{II})$ selective indicator, Org Lett. 15 (2013) 1072-1075 (synthesis of 70 see Supplementary Material), http:// dx.doi.org/10.1021/ol4000873.

[4] A.E. Jensen, P. Knochel, Preparation of 2-arylated-1,4-phenylenediamines by palladium-catalyzed cross-coupling reactions, J. Organomet. Chem. 653 (2002) 122-128 (synthesis of 44 see Supplementary Material), http://dx.doi.org/10. 1016/S0022-328X(02)01156-7.

[5] R. Trokowski, S. Akine, T. Nabeshima, Selective binding of benzenediol derivatives by simultaneous non-covalent interactions in bis-Pt(II) aza-aromatic host-guest system, Dalton Trans. (2009) 10359-10366 (synthesis of 42 see Supplementary Material), http://dx.doi.org/10.1039/B911602H.

[6 M. van der Sluis, V. Beverwijk, A. Termaten, F. Bickelhaupt, H. Kooijman A.L. Spek, Synthesis of novel phosphaalkene-based bidentate ligands Mes*PCH(3-R-Ar) ( $\mathrm{R}=$ Pyridyl, Carbaldimino) and formation of threemembered Palladacycles Mes*(Me)P-CH(3-R-Ar) $-\mathrm{PdCl}$ by Carbapalladation of the PC double bond, Organometallics 18 (1999) 1402-1407 (synthesis of 35 here and also in Supplementary Material), http://dx.doi.org/10.1021/om980913q. 